\title{
4 - "Sem atividade e necessidades, que ainda não são cidadãos úteis" do problema da mão de obra à constituição do povo
}

\author{
Moisés Stahl
}

\section{SciELO Books / SciELO Livros / SciELO Libros}

STAHL, M. "Sem atividade e necessidades, que ainda não são cidadãos úteis": do problema da mão de obra à constituição do povo. In: Louis Couty e o império do Brasil: o problema da mão de obra e a constituição do povo no final do século XIX (1871-1891) [online]. São Bernardo do Campo, SP:

Editora UFABC, 2016, pp. 163-246. ISBN 978-85-68576-85-4.

https://doi.org/10.7476/9788568576854.0004.

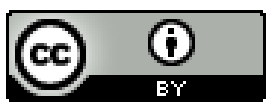

All the contents of this work, except where otherwise noted, is licensed under a Creative Commons Attribution 4.0 International license.

Todo o conteúdo deste trabalho, exceto quando houver ressalva, é publicado sob a licença Creative Commons Atribição $\underline{4.0}$.

Todo el contenido de esta obra, excepto donde se indique lo contrario, está bajo licencia de la licencia $\underline{\text { Creative }}$ Commons Reconocimento 4.0. 


\section{$\{4\}$}

\section{"Sem atividade e necessidades, que ainda não são cidadãos úteis": do problema da mão de obra à constituição do povo}

As discussões sobre a mão de obra no Brasil Império tiveram vários temas que permearam o longo debate que abarcou boa parte do século XIX. No amplo debate sobre o fim da escravidão e os modos de como deveriam ser a substituição da mão de obra escrava por uma mão de obra livre algumas temas foram recorrentes: colonização, imigração, vias de comunicação, agricultura, posse da terra, o papel da pequena e da grande propriedade, o uso de máquinas no cultivo e beneficiamento do café e outras plantas econômicas, qual imigrante seria mais adequado para substituir o trabalho do negro escravizado e os meios científicos de melhorar a produção agrícola. Isto se desdobrava e aparecia um debate sobre quais elementos deveriam constituir o povo brasileiro. A discussão incluía fazendeiros, homens de governo e especialistas, cientistas, que fomentariam alternativas para o recrudescimento da produção, os meios para viabilizar esse aumento e, também discutiam qual mão de obra era mais adequada para o amanho do solo brasileiro. A discussão se desenvolvia em múltiplos fóruns: sociedades 
científicas, associações de classe, tribunas da câmara e do senado e se espraiava pela grande imprensa e pela imprensa especializada. ${ }^{341}$

O debate sobre a mão de obra se adensou entre 1870 até 1888 , período mediado pela Lei do Ventre Livre (1871), pelos Congressos Agrícolas (1878) onde se apontavam diferentes caminhos para o grande tema nacional, até a Abolição (1888). ${ }^{342}$ Nesse momento o nome de Louis Couty foi um dos mais importantes, seus argumentos entraram de forma ativa nas discussões, sedimentando imagens do país e de seu povo, ou da falta deste. Homem de ciência, suas teses sobre o Brasil eram incorporadas no discurso daqueles que faziam da imigração o processo civilizador do país.

\footnotetext{
341 Existe uma ampla bibliografia que discutiu os múltiplos debates e suas dimensões nas décadas finais da Monarquia. Ver entre outros: COSTA, Wilma Peres. "A questão fiscal na transformação republicana continuidade e descontinuidade”, op. cit., 1998, p. 141-173. GEBARA, Ademir. O mercado de trabalho livre no Brasil (1871-1888). São Paulo: Brasiliense, 1986. CARVAlHO, José Murilo de. A Construção da Ordem. Teatro de Sombras. $6^{\circ}$ edição. Rio de Janeiro: Civilização Brasileira, 2011. CONRAD, R. Os últimos anos da escravatura no Brasil (1850-1888). Rio de Janeiro: Civilização Brasileira. INL, 1977. HOLLOWAY, Thomas H. Imigrantes para o café: café e sociedade em São Paulo, 1886-1934. Tradução de Eglê Malheiros. Rio de Janeiro: Paz e Terra, 1984. EISENBERG, Peter L. Homens Esquecidos: escravos e trabalhadores livres no Brasil, séculos XVIII e XIX. $1^{\text {a }}$ edição. Campinas: editora da Unicamp, 1989. A década de 1870 também "é entendida como um marco para a história das ideias no Brasil, uma vez que representa o momento de entrada de todo um novo ideário positivo-evolucionista em que os modelos raciais de análise cumprem um papel fundamental”. SCHWARCZ, Lilia Moritz. O Espetáculo das Raças, op. cit., 2008, p. 14.

342 Cf. Anais do Congresso Agrícola do Rio de Janeiro, 1878. Introdução e notas de José Murilo de Carvalho. Fundação Casa de Rui Barbosa. Edição fac-similar. 1988. GEBARA, Ademir. O mercado de trabalho livre no Brasil (1871-1888), op. cit., 1986.
} 
O problema da mão de obra era preocupação constante no Império como indica o fato de ter sido o que mais vezes apareceu nas Falas do Trono: em 56 Falas 34 o mencionaram. ${ }^{343}$ Nesse sentido, o que se pretende neste capítulo é operar o problema da mão de obra em sua relação com a questão da constituição do povo pelas ideias de Louis Couty. Como a crise da mão de obra era narrada? Como elaborou seus argumentos para intervir nessa crise? Quais conceitos mobilizou para justificar suas teses? Quais eram seus interlocutores diretos e indiretos? Como se deu o debate? Como suas ideias foram absorvidas por um setor da sociedade que propunha reformas através da imigração? Sobretudo, como esse setor tornou-se referência usando Couty? Como nas reformas propostas podemos apreender um debate sobre a constituição do povo mediado por Couty? Sobretudo, como Couty subsidiou argumentos na questão da constituição do povo?

O olhar de Couty em relação ao Brasil é o de um jovem cientista francês que se surpreende com o que encontra e transforma tudo em problema científico a fim de ser solucionado, posto que "não há atualmente país algum onde se encontre reunido tão crescido número de importantes problemas científicos" ${ }^{\text {344 }}$ dizia ele. É a partir dessas novidades e problemas que elabora um projeto para o país, um projeto que teria por base a ciência, seu ofício, com efeito, "se o Brasil é já tão rico para o agricultor, para o comerciante, o é ainda mais para o homem de

343 CARVAlHO, José Murilo de. A Construção da Ordem. Teatro de Sombras, op. cit., 2011, p. 347.

344 COUTY, Louis. “Os estudos experimentais no Brasil”, op. cit., 1879, p. 219 . 
ciência e para o investigador". ${ }^{345}$ Nesse novo, rico e pouco explorado país uma miríade de possibilidades se abriria às mais diversas profissões.

Em 1879, ao descrever as potencialidades do Brasil, dizia quais profissões teriam grande utilidade nesse novo país e entre as profissões citadas estava a do geólogo (solo), do biólogo (homem) e a do economista (produção). Já estava no clima de estudar o Brasil a partir da junção de tais disciplinas. No caso do economista, dizia ele, "cuja ciência tende felizmente a se desprender o mais possível das fórmulas vãs para ater-se à observação precisa de condições as muito diversas, onde encontrará reunidos tantos assuntos interessantes?". No Brasil, respondia ele, onde o economista "pode estudar o termo da escravidão" e elaborar soluções para seu fim, posto que "pode ser estudado em condições tais que se chegue a averiguar se semelhante forma de trabalho com seus defeitos, elevado preço, somenos valia, já não estaria por si mesma condenada”. E continuava Couty observando que o "economista teria ainda de estudar a crise monetária, as oscilações do cambio, e, porque não o direi, se os maiores patriotas o confessem, teria de discutir o futuro financeiro de um país rico por si mesmo", rico por seu "solo e clima", rico porque suas "lavouras já florescentes se multiplicam rapidamente". O economista, pela ótica de Couty, poderia notar que nesse "país" em que suas lavouras se valem de uma "mão de obra primitiva e caríssima, produzem rendimentos muito superiores aos da Europa". Por fim, "surgiria a questão capital da

345 Idem, p. 219. 
transformação da mão de obra”, que "com tanta razão preocupa os espíritos previdentes”. ${ }^{346}$

Um país como o Brasil não poderia deixar de despertar o interesse sobre a composição de seu povo e de sua mestiçagem. Desse modo, pensava Couty que homens como Paul Broca, Quatrefages, Bertillon, Martillet, quanto interesse não teriam de estudar, para o progresso da antropologia, "não só os caracteres étnicos, criminológicos e outros das diferentes raças do Brasil, mas principalmente o cruzamento dessas raças, sua influencia sobre o desenvolvimento orgânico ou intelectual, sobre a fecundidade do mestiço etc.?!”. E como num conselho, "conforme me dizia há poucos meses o Sr. Broca, que país se encontrará, a não ser o Brasil, onde esse estudo possa ser feito facilmente e em boas condições?". 347 Desse modo, estava Louis Couty amparado, aconselhado, balizado pelas maiores autoridades do mundo da ciência.

Procurou seguir o caminho de cada profissão que ele descreveu que poderia transformar o país. Foi múltiplo, ávido, célere, em seus feitos. Acompanhou o ritmo acelerado do desenvolvimento científico e ao mesmo tempo era o próprio desenvolvimento científico. $\mathrm{Na}$ primeira missão científica que chefiou, apreendeu as dimensões do Império e de seus problemas, mas nenhum problema encontrado - insistia Couty - seria capaz de sintetizar a situação do país: "Insisto eu sobre essas questões: se o faço é porque se ligam intimamente à solução do momentoso problema que ora interessa tão perto o Brasil: o problema da mão de obra" ${ }^{348}$

346 COUTY, Louis. "Os estudos experimentais no Brasil”, op. cit., 1879, p. 222. [grifo nosso].

347 Idem, p. 221-222.

348 COUTY, Louis. "A Cultura do Cafeeiro na Província de São Paulo", op. cit., 1879 , p. 163. 
Numa palavra: se o problema da mão de obra era a questão central do Império, sua solução se inseria numa rede complexa de reformas. Ele procurava vê-las a partir dessa ciência nova, a Biologia Industrial, que ele ensinava na Escola Politécnica do Rio de Janeiro.

As análises de Couty sobre a sociedade brasileira de fins do século XIX estavam inseridas num amplo projeto de modernização do país por várias frentes. De um lado o Estado Imperial investindo no desenvolvimento da ciência para modernizar a produção agrícola através da ação cientistas como Couty, Nicolau Moreira, Emílio Goeldi, Ladislau Netto e outros. ${ }^{349}$ De outro lado, setores da sociedade imperial se organizando em defesa da imigração e da abolição. Se Couty se alinhava entre aqueles que viam a saída para o problema da mão de obra na imigração europeia, ele também pensava que a corrente imigratória ao aportar no país proporcionaria uma série de iniciativas que culminariam nas reformas necessárias ao país. Contudo, não bastava pensar numa solução externa sem se mobilizar internamente para atrair essa corrente.

A partir da definição que Couty fez da nova disciplina que ministrou na Escola Politécnica do Rio de Janeiro, a Biologia Industrial, apreendemos os modos pelos quais ele operou uma análise econômica e sociológica do Império do Brasil, matizada pelo racialismo imperante. Foi pelas possibilidades programáticas que Couty incutiu à Biologia Industrial que visualizamos a chave interpretativa pela qual entendeu o Brasil: do solo ao homem. A partir

349 Cf. LOPES, Maria Margaret, op. cit.; GUALTIERI, Regina, op. cit.; CARULA, Karoline, op. cit.; GOMES, Ana, op. cit. 
disso entendemos que o relatório/livro Étude de biologie industrielle sur le café: rapport adressé à $M$. le directeur de l'Ecole Polytechnnique publicado em 1883, reúne o máximo de possibilidades de compreensão das ideias de Couty. É o momento de maturidade de suas observações.

No momento de publicação desse relatório ele estava trabalhando em um projeto grande sobre a composição do cérebro do homem em suas dimensões psíquicas, físicas e sociais. Quanto a isso, segundo Alfredo d'E. Taunay, Couty trabalhava numa obra que trataria do sistema nervoso numa chave analítica que abordaria o aspecto físico e moral e social do homem. No primeiro capítulo dessa obra, trataria dos movimentos cerebrais e nos três capítulos seguintes mostraria como esses movimentos se produzem, bem como suas perturbações por meio do bulbo e da medula. Indicaria a natureza das sensações conscientes e inconscientes para em seguida analisar as funções psíquicas: percepções e ideias, formas conscientes, natureza emocional e social da ideia e "a este respeito, a linguagem - formação da ideia". Além disso, a hereditariedade, o instinto; a educação pessoal ou adquirida. "Os fatores físico-químicos (coma); os fatores biológicos (sono); os fatores sociológicos (loucura). Desenvolvimento cerebral. Resultantes: a personalidade, sua constituição e papel. Variações da personalidade; alcoolismo, histeria, paixões. O modo de proceder; escolha dos motivos ideativos ou sensitivos; liberdade". E, por fim, "associação das personalidades: sociologia". ${ }^{350}$ Além

350 COUTY, Louis. Pequena propriedade e imigração europeia. Obra póstuma anotada e precedida de uma introdução biográfica por Alfredo d'E. Taunay. Rio de Janeiro: Imprensa Nacional, 1887, p. 26-27. Infelizmente, não encontramos esse trabalho de Louis Couty. 
disso, havia percorrido as províncias do Rio de Janeiro, São Paulo e da região Sul, em busca de solucionar a crise da mão de obra e suas crises decorrentes.

A Biologia Industrial visava apreender as complexidades da organização social em todos os níveis, do econômico ao sociológico, passando pelo biológico e dar soluções para os problemas encontrados. Nesse sentido, a mercadoria do ponto de vista da biologia industrial seria considerada como produto biológico do solo e do clima, mas também do homem, resultando do seu trabalho. ${ }^{351}$ Para tanto, compara a Economia Política e a Sociologia com a Biologia Industrial e observava que esta,

penetra mais no problema e especializando-se, estuda o esforço produtivo do homem, considerando-o em relação às suas diferentes necessidades; e em seus esforços, concentra-se especialmente àqueles que tem por objeto a utilização dos seres do reino vegetal ou animal: assim, esta ciência cria uma ligação estreita entre as ciências sociológicas e as ciências biológicas, mantendo um lugar fácil de delimitar. ${ }^{352}$

Aliando a esse instrumental teórico que ele desenvolveu, possuía uma compreensão do mercado e da interligação entre as economias e os efeitos da crise na mercadoria. A mercadoria, segundo Couty, "depende da natureza da mão de obra, de sua perfeição, de seu custo alto ou baixo". Prosseguia, observando que a mercadoria "depende da quantidade de trabalho acumulado, e de

351 COUTY, Louis. Étude de biologie industrielle sur le café, op. cit., 1883, p. 64 .

352 Idem. 
suas formas; depende ainda de fatores sociais mais complexos”. Desse modo, apurava seu argumento notando que "a falta de trabalhadores ativos na Turquia e na Espanha, a crise dos salários na França e na Inglaterra, a insuficiência de capitais, de estradas, de máquinas na Itália e na Grécia, a servidão na Rússia, o aluguel na Irlanda”, somados à "escravidão no Brasil, nos mostram as causas múltiplas que podem alterar a produção e variação do seu preço de custo". ${ }^{353}$

Preocupado em responder os motivos da crise do café, mostrava como o mercado mundial se constituía e como que as relações do mercado e as especificidades de cada país poderiam alterar os preços. Com isso, visava mostrar que a culpa não era apenas do Brasil, mas das consequências de um sistema. Procurava mostrar o caminho para o Brasil se consolidar de forma hegemônica nesse mercado mundial do café e dos demais produtos que por ventura o país viesse produzir.

É importante observar que a estrutura desse livro é consequência de vários estudos, vários relatórios que Couty realizou após vistoriar algumas fazendas das províncias do Rio de Janeiro e São Paulo. Nesse sentido, o relatório/livro sobre a Biologia Industrial do café não foi resultado de uma missão específica, mas da somatória delas. Prova disso é a questão que apareceu no relatório sobre a propaganda do mate, café e carne seca na Europa, que dizia ser alto demais o custo da produção do café. ${ }^{354}$ Daí decorreu a necessidade de elaborar um

353 Idem.

354 COUTY, Louis; TAUNAY, Luiz Goffredo de Escragnolle; TELLES, Augusto Carlos da Silva. Propaganda na Europa do mate, do café e da carne seca, op. cit., p. 24. 
programa de estudos baseado na análise do custo da produção do café. Essa questão está ligada ao problema que Louis Couty formulou para responder qual era a origem da crise do café. Para tanto, "o programa dos trabalhos práticos da cadeira de Biologia Industrial” que a Escola Politécnica aprovou "tem por título: o preço de custo do café”. 355

$\mathrm{Na}$ primeira parte, como já apontamos, ele demonstrava as características do solo, da vegetação e as possibilidades que se pode obter desde que o solo seja muito bem manejado. Na segunda parte Couty analisou a dimensão econômica, do mercado mundial de café, e como a introdução de equipamentos desenvolvidos, praticado em certas fazendas, auxiliaria no aumento da produção do café brasileiro, na melhora da qualidade e no aumento do seu preço rendendo maiores lucros. A atenção dada à mão de obra se deu ao logo das duas partes do relatório. Couty queria mostrar, o que seria sua obsessão, como uma mão de obra cara e de má qualidade impede o maior desenvolvimento da produção e do país. Analisou as várias interfaces da questão. Operou o problema da mão de obra articulando seu olhar de homem de ciência com as possibilidades que a Biologia Industrial oferecia. Por ser uma disciplina nova, entendemos que Couty caracterizou a abordagem dos objetos dessa disciplina a partir de suas convicções, ampliando suas possibilidades. Portando, a abordagem sociológica, propriedade característica da disciplina, era necessária para problematizar o homem no manejo produtivo do

355 COUTY, Louis. Étude de biologie industrielle sur le café, op. cit., 1883, p. 1 . 
solo. Por isso, para Couty, no Brasil, o solo precisava do homem. Dado um solo fértil era preciso transformá-lo a partir de mãos habilidosas, mãos que só deveriam ter uma origem: a europeia. É do ponto de vista da disciplina nova que Couty aborda a sociedade brasileira, que opera os problemas do país pelas ideias novas em voga.

\subsection{O papel da Lei do Ventre Livre (1871) na formação do pensamento de Couty sobre o Brasil}

[...] a lei de 1871 que garante a completa supressão da escravatura em menos de trinta anos, é obra tanto do Imperador quanto de um estadista oriundo do povo, cuja morte recente foi vivamente lamentada: Paranhos, visconde do Rio Branco. ${ }^{356}$

A Lei de 28 de Setembro de 1871, Lei do Ventre Livre, Lei Rio Branco, assumia no pensamento de Louis Couty um aspecto crucial, na medida em que ele via nessa lei o modo mais perspicaz de conduzir a transformação da mão de obra escrava para uma mão de obra livre. A Couty agradava o caráter transitório que a Lei do Ventre Livre impunha no governo da transição. O Brasil observado por Couty era o da transição, e nada mais significativo do que uma lei que conduzisse o processo sem revolução. Apreende a necessidade dos cafeicultores aferrados à escravidão, ao status quo da grande propriedade escravista e nutri essa dimensão reflexiva de um setor social com seu precioso saber científico.

356 COUTY, Louis. A escravidão no Brasil, op. cit., 1988, p. 54. 
A situação atual, dizia ele em seu primeiro olhar (1879), “deve ser apenas considerada como um período eminentemente transitório, tanto mais útil quanto mais curto for". ${ }^{357}$ Suas primeiras observações gerais sobre o que encontrou indicava que o Império do Brasil estava em um momento de transição e a Lei de 28 de Setembro de 1871 cumpriria função estratégica na operação de transformar a mão de obra.

O posicionamento contrário de Couty em relação às transformações abruptas, a abolição imediata, e nesse posicionamento estava seu apreço pela Lei do Ventre Livre, se baseava na sua constatação de que faltava "homens livres ativos, aptos para os trabalhos agrícolas e capazes de uma atividade regular" no Império. Isto é, se fosse abolida a escravidão o Império não teria condições de manter a produção agrícola no nível que se encontrava. Nesses termos, "suprimir bruscamente a escravidão significaria suprimir ou reduzir todas as produções importantes, e fazer secar as fontes da renda nacional ou individual”. As consequências seriam desastrosas na medida em que o Império se encontraria "na impossibilidade de honrar seus compromissos" com os países da Europa. ${ }^{358}$

A Lei do Ventre Livre (1871) se insere num conjunto de leis que visou abolir a escravidão sem acrescer danos à produção agrícola do país, melhor dizendo, sem danos aos grandes proprietários. Além de abolir de forma gradual a escravidão, procurou permitir aos grandes proprie-

357 COUTY, Louis. "Os estudos experimentais no Brasil”. Revista Brazileira; ano 1, tomo 2, p. 232, out./dez. 1879.

358 COUTY, Louis. A escravidão no Brasil. Tradução de Maria Helena Rouanet. Rio de Janeiro: Fundação Casa de Rui Barbosa, 1988, p. 51. 
tários se desvencilhar de seus escravos, de acordo com suas possibilidades, e sem que perdessem o controle sobre a força de trabalho. Seu objetivo era fazer com que os senhores mantivessem os ingênuos até os 21 anos e que depois dessa idade estes contratassem seus serviços aos ex-senhores. ${ }^{359}$ Em seu bojo esta lei trazia o componente decisivo para a organização e disciplina do mercado de trabalho livre no Brasil. Com efeito, a obra de 1871 formulou a estratégia de definição da abolição da escravidão e transição para o trabalho livre, bem como para a configuração do mercado de trabalho livre. ${ }^{360}$

Para embasar seu argumento da necessidade gradual, Couty apontava uma série de hábitos abolicionistas que justificavam, ao seu olhar, o modo regulador de conduzir a abolição total. Eram alforrias que aconteciam acompanhadas de atos festivos onde o senhor concedia a liberdade ao escravo. Aproveitava-se a ocasião de um aniversário, de um casamento para colocar em prática tal hábito. Isto seria por parte do senhor de escravos uma iniciativa que preenchia a "falta de iniciativa individual" dos negros. ${ }^{361}$ Dizia ele que "todas as solenidades, todas as alegrias familiares, todos os grandes acontecimentos domésticos ou nacionais servem de pretexto ou de motivo para tais libertações". ${ }^{362}$ Além disso, outro hábito notado por Couty se dava no leito de morte do senhor que libertava seus escravos mais próximos.

\footnotetext{
359 BARBOSA, Alexandre de Freitas. A formação do mercado de trabatho no Brasil. São Paulo: Alameda, 2008, p. 127.

360 GEBARA, Ademir. O mercado de trabalho livre no Brasil (1871-1888), op. cit., 1986 , p. 11.

361 COUTY, Louis. A escravidão no Brasil, op. cit., 1988, p. 62.

362 Ibidem.
} 
Esses hábitos, Couty os entendia como corriqueiros e era assim que analisava a situação do negro diante do "grande número de libertações". Segundo seus dados, cerca de quarenta mil escravos haviam sido alforriados nos últimos quatro anos, isto é, de 1877 até 1881, a partir de um hábito que em conjunto com as leis possibilitava uma ampla cota de alforrias. Esses hábitos em conjunto com a legislação seriam, para Couty, mecanismos de emancipação baseados no costume nacional.

Pode-se compreender, agora, o mecanismo da emancipação do Brasil. Esta sempre existiu, lenta e progressiva, porque faz parte dos costumes e dos hábitos nacionais. Começou com a mistura de cores, antes das grandes levas de escravos que chegaram no início do século [XIX] e continuou com as alforrias conquistadas individualmente por certas raças e, principalmente, com as numerosas libertações outorgadas pelos senhores de escravos. $^{363}$

Seria a partir dessa observação que Couty entendeu que no Brasil as transformações bruscas não dariam certo, contribuindo assim para a ideologia da permanência no imaginário nacional. Posto que, com hábitos libertários os senhores e a sociedade de modo geral garantiam ao negro livre e fácil entrada como cidadão na sociedade. A única barreira que impedia a ascensão do negro na sociedade seria sua "falta de iniciativa individual". E por não ter esse hábito era preciso substituir seu trabalho por trabalho mais qualificado.

363 Idem, p. 63. 
[...] Os ministros de 1871 tiveram confiança no futuro do País, na sua abundante riqueza, no seu solo, no seu clima, na sua flora tão favorecida. Compreenderam que o que faltava a essas riquezas naturais, sem valor por si só, era a mão de obra inteligente e ativa e o equipamento social que deviam torná-las úteis e vantajosas [...]. ${ }^{364}$

A base de sustentação do argumento de Couty sobre a força da Lei do ventre Livre, encontra-se na citação acima. Couty entendia o país como uma pedra preciosa bruta à espera de ser lapidada, polida, a fim de reluzir num futuro esplendoroso. Tinha um solo e um clima de ótima qualidade. Tendo toda essa riqueza, o que faltava? A mão de obra qualificada, ativa, capaz de produzir o melhor em prol do país. Mas qual mão de obra deveria aportar no país? A europeia, com sua organização ativa e próspera fomentaria um povo novo e hábil na condução do progresso. O Brasil possuía o solo, mas precisava do homem. E a lei de 28 de setembro de 1871 cumpria papel nessa revolução lenta e gradual sonhada por Couty.

Assim sendo, as estradas de ferro se estenderam rapidamente a partir de 1871 e várias províncias importantes já se tornaram, desta forma, acessíveis. Em São Paulo ou Minas, podemos ver estradas transformando a floresta virgem, à medida que vão avançando, em novas regiões habitadas e cultivadas. ${ }^{365}$

Louis Couty viu uma ação modernizadora dessa lei, na medida em que após ela, o país presenciaria o

364 Idem, p. 71. [grifo nosso].

365 COUTY, Louis. A escravidão no Brasil. Op. Cit. 1988, p. 72. 
aparecimento de uma rápida expansão das linhas férreas. Nessa relação que Couty empreendeu, o país estaria preparando o ambiente para um maior desenvolvimento com a imigração. Por acreditar que "não existe transformação brusca em lugar nenhum", o ato da Lei de 28 de setembro de 1871 era a maneira mais adequada de conseguir a transformação desejada do trabalho escravo para o trabalho livre.

Jamais acreditei na influência criadora de qualquer legislador. Acho que as reformas mais justas, mais úteis em si mesmas, só podem dar resultados depois de terem sido preparadas e tornadas necessárias através do meio, dos costumes, do conjunto das condições biológicas e sociológicas. Os artigos de lei não possuem virtude mágica que os torne capazes de transformar, em pouco tempo, milhões de homens de raças diversas e de constituir cidadãos ativos e econômicos em locais onde o trabalho livre está apenas se iniciando. ${ }^{366}$

Para Couty, a lei só cumpriria sua obra se a ela fosse ajustada às ações em conjunto dos fazendeiros. O principal aspecto que Couty assimila dessa lei foi o do costume, tão caro a ele. Por ser tal lei elaborada no bojo de costumes, ela teria resultados mais significativos do que uma lei que pusesse fim ao trabalho escravo e deixasse os fazendeiros na mão. É importante contrastar essa ideia de Couty com o que colocou Alexis de Tocqueville sobre a emancipação dos escravos nas colônias francesas da primeira metade dos Oitocentos. Analisando as duas

366 Idem, p. 89. 
formas, gradual e direta, de realizar a abolição, Tocqueville notava que a abolição "simultânea" - direta - de todos os escravos seria a melhor solução para as colônias da França. Enquanto que a abolição gradual oferecia inconvenientes e mais perigos por apresentar como consequência a formação de uma classe à parte para quem seria necessária a criação de uma legislação especial; haveria ao mesmo tempo homens livres e escravos, sendo os livres abusadores de sua independência ao levarem uma vida "ociosa e vagabunda". O trabalho, nessas condições, se manteria como o estigma da escravidão e "cada negro que consegue a liberdade é, naturalmente, levado a considerar o ócio como o mais doce e o mais glorioso privilégio da sua nova condição". 367

Louis Couty não vai comungar do mesmo pensamento de Tocqueville, nem do pensamento dos abolicionistas brasileiros e, sobretudo, nem do pensamento de Victor Schoelcher, pois queriam a abolição total. Desse modo, o debate que Couty teve com Schoelcher e com os abolicionistas brasileiros é decorrente dessa interpretação. Os únicos homens capazes de conduzir a transformação do trabalho seriam, para Couty, os fazendeiros e a lei de 1871 se realizaria na ação desses fazendeiros.

\subsection{0 escravo e sua enxada}

[...] o Sr. Dr. Luiz Couty que, em numerosos trabalhos que correm impressos, e em artigos notáveis

367 TOCQUEVILLE, Alexis de. A emancipação dos escravos. Tradução de Fany Goldfarb. Campinas: Papirus, 1994, p. 38-40. 
que tem aparecido no Messager du Brésil, tem demonstrado que o trabalho escravo é mau e caro, que o trabalho nacional é numericamente insuficiente, e pelas suas condições naturais incapaz de por si só dar a exploração de nossos recursos o impulso necessário. ${ }^{368}$

O trecho acima é de Ferreira de Araújo, e a menção que o jornalista fez a Louis Couty demonstra o quanto suas ideias sobre a questão da mão de obra eram aceitas como referência no assunto. Ao mesmo tempo é evidência de sua inserção nas discussões sobre as questões que mais urgiam na década final do Império do Brasil.

Nesse quadro, Louis Couty caracterizou o trabalho do negro escravizado e após essa caracterização atribuiu ao trabalho escravo a culpa pela crise que passava a lavoura de café entre as décadas de 1870 e 1880. Em sua descrição, o trabalho do escravo era mau e caro, não possibilitava boa produção e nessa produção os frutos do café, por exemplo, eram de má qualidade. Mas, apesar do trabalho do negro escravizado ser constantemente criticado, Couty abria uma única exceção para os negros-mina. Na hierarquização racial e laboral dos negros feita por Couty, os mina tinham conseguido "tirar proveito de condições tão favoráveis” que o regime escravista

\footnotetext{
368 Gazeta de Notícias, 16 jun. 1884. O artigo esta presente na seção “Cousas Políticas”. Apesar de não aparecer o nome do autor do referido artigo, entendemos que seja Ferreira de Araújo, porque em outras oportunidades Couty se referiu a esta seção como sendo assinada pelo sócio proprietário da Gazeta de Notícias. Além disso, Ferreira de Araújo publicou um livro onde reuniu seus artigos com o título Cousas Politicas: artigos publicados na Gazeta de Notícias de março a dezembro de 1883. Rio de Janeiro: Tipografia da Gazeta de Notícias, 1884.
} 
possibilitava. Essas condições favoráveis mencionada referem-se à entrega negociada de porções de terras que o senhor fazia para com os escravos, sendo os mina os únicos que souberam aproveitar tal benesse. Enquanto os "outros negros, isto é, a quase totalidade dos indivíduos da raça, não souberam fazer qualquer esforço para conquistar a própria liberdade" dizia Couty. ${ }^{369}$

Na caracterização do trabalho escravo vamos notar o argumento de Couty se relacionando com os propósitos da Lei do Ventre Livre, ou seja, ao argumento da emancipação gradual e "progressiva" como ele gostava de dizer. Para ilustrar o que pensava, recorria a elementos cotidianos da vida brasileira.

Poderia citar fatos cotidianos, que todos já presenciaram: este escravo é bom cozinheiro, esse outro é carregador, carpinteiro ou pedreiro, e todos eles trabalham bem. Eles são libertados e, pouco tempo depois, tendo-se tornado beberrões ou preguiçosos, só trabalham quando obrigados por necessidades muito limitadas $[\ldots] .{ }^{370}$

Nesses termos, estava em risco a produção agrícola, caso fosse realizada a abolição em 1881, ano que fez a observação. Na imagem de Couty, os negros libertos não continuariam na produção agrícola e por isso a abolição gradual ajustaria a libertação dos negros à chegada de imigrantes para substituí-los, já que quando libertos os negros não trabalhariam mais. Além disso, se o negro não fosse subjugado ele não trabalhava. O escravo

369 COUTY, Louis. A escravidão no Brasil, op. cit., 1988, p. 62.

370 Idem, p. 66. 
não teria motivação, iniciativa, como queria Couty e por isso pouca aptidão para o trabalho produtivo. Dizia Couty que se alugado fosse o escravo quem ganhava com seu aumento era seu dono, "se fica em casa do proprietário, tem menos ainda a esperar". Com isso, sabia que "se o senhor estiver tendo lucro com ele, lhe dará sempre comida para vê-lo gozando de boa saúde". Se já tinha o alimento não teria "esforço" nem "luta individual" e assim estava com "o amanhã” garantido "já que representa um capital e não um indivíduo" ${ }^{371}$ O negro, portanto, não seria um indivíduo social útil, o negro para Couty não seria um indivíduo, seria um capital empregado com todos os riscos de perdas e ganhos. Seus argumentos iam de encontro aos interesses dos cafeicultores, sempre contra o negro escravizado.

Desde seu início no Brasil, concebe o trabalho escravo como "raro" e "caro" e, sobretudo de má qualidade, por isso precisava ser substituído. Em 1879, no reconhecimento, atuava como mediador de ações que poderiam aumentar a produção e via no uso de máquinas e instrumentos como a carpideira uma possibilidade de substituir o trabalho escravo. Nesse cenário se questionava e questionava os leitores: "a mão de obra escrava deve ser substituída pelas máquinas agrícolas? Efetivamente será este o meio mais adequado de tornar o trabalho menos raro e, sobretudo, menos caro" no Brasil. Se isso aparecia como solução mais adequada, como "operar semelhante transformação do trabalho?". Nisso se abria as possibilidades de transformação não apenas da mão de obra, mas

371 Idem, p. 76. 
de todo o aparato produtivo da agricultura do Império. Para tanto, Couty questionava se nessa transformação caberia o uso do arado europeu "que se destina a revolver as camadas superiores do solo para lavouras anuais, será conveniente num solo arável muito espesso e principalmente para lavouras de raízes profundas, como cafeeiros, algodoeiros, canas, muitas vezes antigas?". Ou, se esse arado feito para o solo europeu poderia ser substituído por um fabricado no Brasil, portanto, "mais apropriado ao solo e às lavouras do Brasil?”. Para Couty, essas questões poderiam "ser resolvidas por um engenheiro especialista, mediante observações e experiências precisas, feitas por si mesmo ou pelos fazendeiros, cujo concurso de certo não lhe faltará". ${ }^{372}$ Essas questões e soluções colocadas por Couty sobressaem num pano de fundo que tinha o trabalho escravo como predominante, porém esse trabalho escravo estava com seus dias contados por obra da Lei do Ventre Livre. Nesse sentido, Couty visava uma transformação mais completa e intensa ao incentivar a criação de equipamentos adequados à realidade do solo brasileiro sem ter que recorrer aos produzidos na Europa ou Estados Unidos. Exemplo desse incentivo encontra-se na criação da Máquina de Secar Café Taunay-Telles produzida pelos engenheiros e professores Goffredo Taunay e Augusto Telles no laboratório de Biologia Industrial da Escola Politécnica dirigido por Couty. Somado a isso, viria os imigrantes, que na concepção de Couty seriam os mais aptos a manejar e a criar tais tecnologias.

372 COUTY, Louis. "Os estudos experimentais no Brasil". Revista Brazileira, ano 1, tomo 2, p. 223, out./dez. 1879. 
A narrativa que Couty fez sobre o que viu pelas fazendas que visitou e paisagens que observou, além dos relatos que obteve de outrem, tinha um cenário em que o trabalho escravo se manifestava e se relacionava com o que ele classificou de primitivo, atrasado, de entrave. Assim, dizia ele que os "cafezais cultivados pelos escravos são trabalhados com o auxílio de métodos primitivos". Não havia inovação no trabalho escravo, nem automação. Apesar disso, não negava que as plantações "em geral muito bem tratadas [...] causariam a admiração de nossos agricultores" europeus, sempre "mais exigentes". Todavia, toda essa produção requeria "um imenso dispêndio de mão de obra”. ${ }^{373}$ Tornando-se um entrave na medida em que as fontes de obtenção do trabalho escravo - tráfico transatlântico e nascimento ${ }^{374}$-, haviam secado, sobretudo com a Lei do Ventre Livre (1871). Além disso, Couty via a simbologia do atraso do trabalho do escravo num instrumento que segundo suas observações "revolvia à mão" a terra. Era com auxílio dessa "espécie de instrumento" de cavar que o escravo trabalhava o

373 COUTY, Louis. A escravidão no Brasil, op. cit., 1988, p. 78-79.

374 Citando Perdigão Malheiro, Barbosa observa que em 1850 com a abolição do tráfico transatlântico de escravos, o país viu esgotar a infame fonte de braços africanos a serem escravizados. Assim, com a Lei Eusébio de Queirós, de 4 de setembro de 1850, o regime escravista encontrava um limite. Segundo Perdigão Malheiros, a escravidão até 1850 estava alicerçada em duas bases: de um lado o tráfico transatlântico de africanos, e de outro lado a hereditariedade e perpetuidade pela reprodução. Com a Lei Eusébio de Queirós apenas uma base permanecia de sustentáculo para o regime. BARBOSA, Alexandre de Freitas, op. cit., 2008, p. 94. Com a Lei do Ventre Livre as duas fontes secavam. 
solo. ${ }^{375}$ Esse instrumento era a enxada, que no olhar de Couty não seria nada além da extensão da mão do escravo, por isso primitivo, pois não dava autonomia ao manter o trabalhador em contado direto com a produção.

O que faltava nessa paisagem da produção cafeeira que tinha o trabalho escravo como principal força? Se o trabalho escravo era primitivo, caro, necessitando de um elevado contingente de trabalhadores que já se encontravam em condição de escassez, por isso também raro, era preciso substituir num primeiro momento, ainda que de modo gradual, os escravos por máquinas e instrumentos agrícolas. Essas máquinas e outros instrumentos desejados por Couty no cafeeiro eram, em 1881, segundo ele "introduzidos em raros pontos do país". 376

Essas conclusões de 1881 sobre o negro e sua enxada não serão alteradas anos mais tarde, em 1883, no seu relatório/livro sobre o café. Se em 1879 Couty considerava a mão de obra escrava inferior e que eram poucas as iniciativas tecnológicas empregadas na produção cafeeira, em 1881 corroborou seus primeiros diagnósticos e, em 1883, em seu mais completo trabalho sobre a produção do café, enfatizava que "comme conclusion, partout où cela est possible, on devra remplacer le noir et son exada par le mulet et la capideira". ${ }^{377}$ Para seu argumento estava claro que nesse curto percurso de tempo, o trabalho do escravo não tinha evoluído, confirmando assim o que pensava desde o início.

375 COUTY, Louis. A escravidão no Brasil, op. cit., 1988, p. 78-79.

376 Ibidem.

377 "Como conclusão, onde for possivel, devemos substituir o negro e sua enxada pela mula e carpideira”. Tradução Livre. COUTY, Louis. Étude de biologie industrielle sur le café, op. cit., 1883, p. 27-28. 
A Gazeta de Notícias, analisando seu relatório sobre o café de 1883, concordava com suas ideias, mas colocava oposição em alguns aspectos, especialmente, "no que diz respeito ao amanho do solo, ao ensaio de culturas novas e ao emprego de estrumes”. Contudo, em relação à mão de obra: "O que é necessário fazer, quanto antes, é melhorar e tornar mais abundante a mão de obra agrícola entre nós, diz acertadamente o Dr. Couty". ${ }^{378}$ Essa abundância de mão de obra era em relação à mão de obra imigrante, posto que era esse o cenário idealizado por Couty: o de um enorme contingente de imigrantes europeus trabalhando em pequenas propriedades.

A produção do negro nas fazendas, segundo as observações de Couty, era irregular, já que o negro seria incapaz de realizar "operações mais aperfeiçoadas de cultivo". Além disso, a produção do trabalho escravo estava sujeita às intempéries do tempo e necessitava de constante vigilância, posto que "são necessários mais feitores para vigiar trezentos escravos do que contramestres para fiscalizar mil e duzentos trabalhadores livres”, o que significava uma importante diferença no preço do custo do trabalho. Com o negro o fazendeiro despenderia mais gastos para manter vigiada a produção, com o imigrante isso não ocorreria. ${ }^{379}$

Esses problemas que Couty visualizou na produção do café implicaria para ele na má qualidade do produto no mercado. Má qualidade que seria refletida no baixo preço do produto e no menor lucro. Para Couty, essa

378 A Gazeta de Noticias, 12 ago. 1883.

379 COUTY, Louis. A escravidão no Brasil, op. cit., 1988, p. 79. 
situação “desfavorável” permaneceria enquanto "a mão de obra direta do escravo não fosse substituída por diversas máquinas já bastante aperfeiçoadas". 380

Na vistoria dos espaços de produção do café entre 1881 e 1883, Couty se preocupa em saber "se a crise atual do café não tinha suas causas na própria fazenda, em seus métodos de cultivo ou organização [...]" ${ }^{381}$ Nessa missão, observou e descreveu todos os percursos da produção do café, do preparo do solo até a lavagem do café e da ação do trabalho escravo nesse processo. Atento a isso notava que o sabor do café, bom ou mal, era decorrente de todo o processo de preparo do solo até a secagem e embalagem do café a ser vendido. Na percepção de Couty, as falhas ao longo do processo culminariam na alteração do sabor, daria ao café o temido goût de terroir que atrapalhava a fama do café brasileiro. ${ }^{382}$ Por isso sua preocupação em chamar a atenção para cuidados que podiam ser desprezados no processo de cultivo e preparo do café. Todos os possiveis defeitos que o café adquiria, todas as falhas de sua dinâmica no mercado internacional, Couty atribuía ao trabalho escravo.

Para ele, a qualidade na produção dos frutos iria fornecer frutos regulares. Assim, uma espécie de mantra ditava o ritmo de suas ideias: "melhor cultivar, melhor colher, melhor secar", só assim se teria um fruto melhor, mais regular, padronizado. Em decorrência da melhora

380 Idem.

381 COUTY, Louis. Étude de biologie industrielle sur le café, op. cit., 1883. s/p.

382 Numa tradução livre: “gosto de terra”. COUTY, Louis. Étude de biologie industrielle sur le café, op. cit., 1883, p. 33-34. 
da produção o fazendeiro sentiria o aumento nas vendas. ${ }^{383} \mathrm{Com}$ isso, Couty procurava em todas as possibilidades enfatizar que os erros da produção eram decorrência da qualidade ruim da mão de obra escrava e que havia uma solução, desde que o país se movimentasse, se organizasse, para receber imigrantes. Imigrantes que trariam inovações e empreenderiam o uso de máquinas e equipamentos capazes de aumentar a qualidade e a produção do café.

Em um artigo na Gazeta de Notícias de título "Inferioridade econômica do escravo", um autor, que não teve seu nome indicado, ao analisar a questão da mão de obra escrava observava que:

O trabalho escravo é o mais barato de todos, pois não é pago - dizem ainda hoje não poucos fazendeiros, e contrariá-los torna-se difícil, em vista da carência de estudos precisos, feitos no Brasil, sobre a mão de obra servil e o rendimento. ${ }^{384}$

Sentida a carência de estudos, num cenário de carência e carestia de braços, até para contrapor o argumento dos fazendeiros, os trabalhos de Louis Couty ocuparam esses espaços vazios e ao preenchê-los era alçado como referência no tocante aos estudos da mão de obra. Para tanto, o artigo da Gazeta de Notícias prosseguia indicando que:

A brochura do Dr. Couty, relativa ao café, de que já demos conta nesta folha, permite rebater tal

383 COUTY, Louis. Étude de biologie industrielle sur le café, op. cit., 1883 , p. 56-60.

384 Gazeta de Notícias, 21 ago. 1883. 
asserção [de carência de estudos], e evidencia que o trabalho escravo é o mais caro de todos, porque, se despende pouco, rende menos ainda. ${ }^{385}$

O autor do artigo concluía, com Couty, quando descrevia os problemas da mão de obra escrava com trechos de Couty para apontar que o custo elevado das fazendas de café era elevado porque tinha o escravo como principal força, "eis o que provou o Dr. Couty". 386

Os relatórios e livros de Couty nesse contexto de ausência de estudos indicada pelo artigo da folha apontava que a mão de obra escrava era mais cara ao exigir custos de manutenção e por render pouco ao fazendeiro, especialmente quando posta em comparação com os resultados de máquinas e do trabalho do imigrante europeu. Desse modo, diante da ausência de estudos, os relatórios de Couty formavam as concepções sobre a inferioridade do trabalho do negro escravizado como podemos notar.

O movimento das ideias de Couty nesse contexto de transição do trabalho escravo para o livre encontrava nos meios de comunicação, nos jornais e revistas um meio de ampliar e consolidar o discurso da urgência, do ponto de vista de Couty, não de abolir a escravidão, mas antes atrair imigrantes a fim de que ao ser realizada a emancipação dos escravos os fazendeiros não se preocupariam com as consequências da abolição, manteriam a produção em sua continuidade. Sobretudo, era preciso atrair imigrantes e substituir o trabalho escravo "não porque seja prejudicial a uma classe de homens [aos

385 Idem. [grifo no original].

386 Idem. 
fazendeiros], mas porque é prejudicial a toda uma evolução social" ${ }^{387}$ Isto é, para o cientista francês, o negro não seria um problema econômico, seria um problema na evolução social do país. Com esses argumentos, Couty sedimentava a ideia de que o negro não seria útil como elemento constituinte do povo brasileiro.

\subsection{0 domínio da máquina sobre a enxada}

Louis Couty não via evolução no trabalho manual, por isso, ao comparar o trabalho do escravo com o de máquinas ou instrumentos sempre enfatizava a qualidade e a homogeneidade que o processo mecânico possibilitava. Além disso, a perda na produção seria menor quando comparada com a perda no processo realizado pelo trabalho escravo. Com o uso de máquinas e instrumentos agrícolas o fazendeiro evitaria o emprego direto da mão de obra escrava na produção, podendo realocar essa mão de obra em outras atividades. ${ }^{388}$ Couty procurava mostrar que com as inovações a produção ganharia qualidade e produtividade. Sobretudo, o fazendeiro diminuiria os custos com a mão de obra escrava. ${ }^{389}$ Com a produção manual, o café estava sujeito às intempéries do dia ou da noite. Está sujeição ao tempo, além de atrapalhar na produção, proporcionava aos escravos uma condição de vulnerabilidade, na medida em que diante de uma chuva noturna eram "arrancados violentamente"

387 COUTY, Louis. A escravidão no Brasil, op. cit., 1988, p. 74.

388 COUTY, Louis. “Maquina de secar café”, op. cit., 1880, p. 205.

389 Idem, p. 205-206. 
do sono diretamente para o terreiro e proteger o café da umidade, vindos assim quentes da cama, sem precaução alguma, "expor-se às intempéries e esvaziar o terreiro, para talvez tornar a enchê-lo no dia seguinte, passada a tormenta. Quantas moléstias não são devidas a isto?”. Sendo o escravo um capital do fazendeiro, ao se sujeitar a essas doenças, estaria o fazendeiro perdendo, não lucro, mas também um instrumento capitalizado. Couty não estava preocupado com a saúde do negro, mas sim com a perda da mão de obra, isto é: "Sabem os fazendeiros que muitos escravos são vítimas de pneumonias e outras afecções apanhadas nessas ocasiões, dai provindo perda considerável e definitiva de mão de obra". ${ }^{390}$ Os cálculos de Couty tinham o objetivo de mostrar ao fazendeiro o que seria melhor para a sua produção.

Para demonstrar a superioridade da máquina sobre o braço escravo, elaborou alguns cálculos a fim de conquistar o interesse do fazendeiro. Assim, ao utilizar uma máquina o fazendeiro estaria livre de vários custos que oneravam a operação produtiva da fazenda, mas além de reduzir os custos com a mão de obra, o fazendeiro, ao utilizar uma máquina estaria livre de outros custos secundários como o de alimentar e vestir seus escravos. ${ }^{391}$ Outro aspecto dessa redução dos custos enfatizados por Couty se encontrava no aparato de montagem de uma fazenda. Com máquinas de secar o café não seria mais necessário à instalação de terreiros de secagem do café. Ao ser utilizada "uma máquina [...] seja qual for o seu

390 COUTY, Louis. “Maquina de secar café (sistema Taunay-Telles)”, op. cit., 1883, p. 36. [grifo nosso]

391 Idem, p. 36-37. 
preço definitivo, será sempre muito menos dispendiosa do que a instalação de terreiros [...]" onde atuava o escravo. ${ }^{392}$

\subsection{A inferioridade do trabalho escravo em sua longa duração}

[...] sua produção [do escravo] é muito cara, de má qualidade e pouco abundante. Tudo isso é hoje em dia demonstrado por vários estudos precisos que não podemos aqui resumir e a inferioridade do negro em relação ao homem livre não é negada por mais ninguém. ${ }^{393}$

Louis Couty asseverou isso em 1884, mas frase semelhante poderia ser encontrada em seus escritos em 1879, quando chegou ao Império do Brasil e lançou seu primeiro olhar. A ideia da inferioridade do negro e do seu trabalho, como disse Couty, era objeto de vários estudos que argumentavam com a finalidade de justificar essa dita inferioridade laboral e, também, intelectual. Quanto aos estudos que procuravam demonstrar a má qualidade do trabalho do negro, Couty já era, nesse aspecto, um desses estudos como fica demonstrado na citação seguinte:

Desse conjunto de fatos ressalta uma conclusão: o custo da produção do café no Brasil é exagerado. A nosso ver, é isso devido à natureza da mão de obra, que é cara e má; e ao seu emprego direto em excesso. Louis Couty (L'esclavage au Brésil)

392 Idem, p. 37.

393 COUTY, Louis. "Exploração e colonização”. (4 a 11 nov. 1883). In: O Brasil em 1884: esboços sociológicos, op. cit., 1984, p. 80. [grifo nosso]. 
procurou mostrar que o trabalho escravo importa em duas vezes mais do que o de um trabalhador livre na Europa. Os seus cálculos foram impugnados, porém é fácil reconhecer que são exatos, quando não se conta e compara só como despesa o dinheiro desembolsado. O assalariado na Europa é alugado para certo fim, e pago apenas pelo trabalho feito, cabendo-lhe tratar do sustento seu e de sua família. Com o escravo o caso é outro - é necessário contar com uma manutenção, tratamento durante as moléstias, velhice, capital empregado na compra, extinção desse por morte, obrigação de carregar com o mesmo ônus quer a colheita seja abundante ou pequena etc. Evidentemente, em tal fator encontra-se a explicação do alto custo de produção do café, e por conseguinte, a causa principal da crise atual; a supressão progressiva dessa forma de trabalho. Talvez seja o único meio eficaz de fazê-la cessar. Além de custosa, a mão de obra escrava é má. ${ }^{394}$

O texto acima reproduz o raciocínio de Couty sobre a má qualidade da mão de obra escrava, especialmente no aspecto que Couty relacionou, ou seja: o alto custo da produção do café tinha origem na má qualidade da mão de obra escrava. Esse argumento construía a necessidade da substituição dessa mão de obra de má qualidade e pouco abundante por uma mão de obra melhor. Nesse contexto, a inferiorização do trabalho do negro escravizado ganhava no Brasil, pela intervenção teórica de Couty, novos significados que eram assimilados na discussão da

394 O brado da lavoura, 29 ago. 1883. APESP: Ofícios Diversos (Mogi-Mirim), ordem 1121. Apud GONÇALVES, Paulo Cesar. Migração e mão de obra: retirantes cearenses na economia cafeeira do centro-sul (1877. 1901). São Paulo: Humanitas, 2006, p. 80. 
mão de obra naquele momento. Desse modo, suas ideias eram compartilhadas e amalgamadas aos interesses da substituição do escravo pelo trabalhador livre europeu.

A suposição de que o trabalho escravo era inferior ao trabalho livre vem da crítica dos economistas políticos à escravidão, que apareceu nos textos dos fisiocratas e teve continuidade em Adam Smith, se estendendo pela economia clássica. De modo geral essa corrente de pensamento baseava-se no princípio de que o trabalho escravo era o mais caro de todos. Esse princípio da inferioridade do trabalho escravo desdobrava-se em um conjunto de ideias como baixa produtividade do trabalho escravo, resistência do escravo ao trabalho, impossibilidades de inovações técnicas na organização escravista. ${ }^{395}$

Essa ideia econômica da inferioridade do trabalho escravo se formou ao mesmo tempo em que a ciência incutiu uma classificação racial dos povos. O momento pós-descobrimento do Novo Mundo marcou a vida da humanidade ao revelar novos povos que até então se mantinham distante do olhar europeu em seu devir colonizador. Na medida em que os europeus colonizadores passaram a narrar os outros povos que encontravam em

395 ROCHA, Antonio Penalves. A economia politica na sociedade escravista: um estudo dos textos econômicos de Cairu. São Paulo: Hucitec, 1996, p. 119. No caso brasileiro, como assevera Rocha, edificado sobre uma base escravista as ideias da Economia Política, gestada numa realidade europeia em que o trabalho livre se tornava dominante no mundo do trabalho, deveriam, por suposição, se opor ao antiescravismo da Economia Política. Contudo, "as ideias econômicas sobre a escravidão não só entraram no Brasil, como também aqui se acomodaram e, prestando serviços às representações dessa sociedade, chegaram até mesmo a justificá-la, sem que se desligassem formalmente da Economia Política”. p. 119. 
suas expedições, num processo de expansão, tais narrativas construíam o imaginário, dando uma "consciência planetária". ${ }^{396}$ Narrar, coletar, classificar tudo de um ponto de vista dos países centrais do processo de colonização do Novo Mundo era o mote da expansão. Nesse contexto, dois acontecimentos marcam o modo como o europeu vai estabelecer a base material e imaginária do que eles eram e de como eram os outros povos que no caminho fossem encontrados. Um acontecimento foi o tratado científico de Carl Linné, publicado em 1735. Nessa obra, Sistema Naturae, ele estabelece um sistema de classificação que visou categorizar todas as formas vegetais do planeta, fossem elas conhecidas ou desconhecidas dos europeus. Outro acontecimento importante para a análise do entendimento das formas que delinearam a organização social e sua imaginação do real foi a inauguração da primeira expedição científica internacional da Europa - conhecida como "La Condamine" -, um esforço conjunto visando determinar a forma exata da terra. Para Mary Pratt, estes dois eventos, e sua coincidência, sugerem a importante magnitude das mudanças no entendimento que as elites europeias tinham de si mesmas e de suas relações com o resto do mundo, ${ }^{397}$ ou do mundo que se criava na narrativa. Partia-se, portanto, com um método classificatório, a fim de descrever por comparação

\footnotetext{
396 Segundo Mary Pratt, “consciência planetária” é resultante da exploração dos países europeus pelo interior do Novo Mundo e da África, decorrendo uma construção do significado em nível global dessa ação por meio dos aparatos descritivos da história natural. Esta consciência planetária "é o elemento básico na construção do moderno eurocentrismo”. PRATT, Mary Louise. Os olhos do império: relatos de viagem e transculturação. Tradução de Jézio Hernani Bonfim Gutierre. Bauru: Edusc, 1999, p. 42.
}

397 PRATT, Mary Louise. Os olhos do império, op. cit., 1999, p. 42. 
o que fosse encontrado, tendo assim como referência o modelo europeu.

A obra de Carl Linné vai introduzir a classificação das pessoas, sendo o rótulo homo sapiens de sua autoria. ${ }^{398}$ No século XVIII, Linné hierarquizou os grupos humanos existentes em termos taxinômicos modernos. Em sua classificação e hierarquização o homo sapiens afer (negro africano) era governado pelo capricho; enquanto o homo sapiens europaeus era governado pelos costumes. ${ }^{399}$ Linné classificou o americano como amante da liberdade, governado pelo hábito e o asiático como melancólico, governado pela opinião e preconceitos. Outros caracteres que Linné atribuiu ao negro e ao branco cabem ser ressaltados. O negro, além de governado pelo capricho, ou seja, sem governo, necessitando ser governado, também era indolente, negligente. O branco, além de governado pelos costumes, era musculoso, engenhoso, inventivo. ${ }^{400}$

Essas características físicas, sociais, biológicas dos povos - especialmente as comparações entre negros e brancos - percorreu o século XIX, ápice do pensamento científico, acumulando novas caracterizações que em geral não fugiam do que propôs Linné no século XVIII. Nesse sentido, Louis Couty quando asseverava que o trabalho do negro era caro, que o negro com sua enxada não possibilitariam inovações, que o negro precisava ter seu

\footnotetext{
398 Idem, p. 68.

399 GOULD, Stephen Jay. A falsa medida do homem. Tradução de Valter Lellis Siqueira. 3. ed. São Paulo: Martins Fontes, 2014, p. 21.

400 MUNANGA, Kabengele. Uma abordagem conceitual das noções de raça, racismo, identidade e etnia. Palestra realizada no $3^{\circ}$ Seminário Nacional de Relações Racial e Educação - PENESB, 5 nov. 2003. Disponivel em: < https://www.ufmg.br/inclusaosocial/?p =59>. Aceso em: 18 ago. 2014.
} 
trabalho vigiado de forma constante, estava retomando as formulações de Linné adaptando-as na realidade brasileira. Em contrapartida, o trabalho do imigrante europeu seria a solução para a crise que advinha do trabalho escravo. E o mesmo se dava com sua visão da Lei do Ventre Livre (1871), uma lei baseada nos costumes dos homens que governavam o Império.

A construção textual de Couty insere-se nessa longa narrativa que, desde Linné, inferiorizou o negro sob dois pontos de vista: da Economia Política e da Ciêncial Biologia. Com efeito, nesse longo pensamento que intencionou inferiorizar o trabalho escravo, Couty, na realidade brasileira, atua por vias que ele construiu, entende-se aqui a disciplina de Biologia Industrial, em conjunto com suas ações como cientista e mediador cultural no amplo aspecto que esta mediação pode ser entendida, isto é: no campo material e intelectual de realizações. Na descrição que fez Couty dessa nova disciplina, apreendemos os meios que ele elaborou para refletir a realidade brasileira do século XIX. Mesclou elementos da economia, da ciência biológica, da fisiologia e forjou a Biologia Industrial, meio pelo qual operou na realidade brasileira as correntes de pensamento do Velho Mundo.

Para justificar a necessidade de substituir o escravo pelo imigrante europeu, elaborou uma interpretação de seu momento que tinha na ideia de Biologia Industrial o ponto chave que possibilitou a ele insistir na hipótese da inferioridade do trabalho escravo. De fato Couty não foi original em concluir que o trabalho escravo era inferior, com efeito, ele se insere numa longa tradição que elaborou teses que visavam classificar o negro escravizado como inferior, hierarquizando seu lugar na sociedade. Nessa longa tradição, Couty incutiu novos elementos 
atrelando reflexões da nascente sociologia a aspectos biológicos. Nesses termos asseverava Louis Couty, "seguindo a ideia muito verdadeira de Bacon, bem desenvolvida atualmente por Spencer, os corpos sociais são comparáveis a organismos vivos, todas as partes se ligam mais intimamente umas as outras, em medidas perfeitas". ${ }^{401}$

Nessa comparação do organismo social como organismo vivo, com suas doenças e lesões que comprometiam o pleno desenvolvimento, Couty elaborou uma ideia que colocava a mão de obra do negro africano como entrave para o desenvolvimento harmonioso da sociedade, posto que atrapalhava o desenvolvimento produtivo, sobretudo o desenvolvimento social. O negro seria uma lesão que impediria a saúde do corpo social. Não havia encaixe do trabalho do negro escravizado com uma produção uniforme, padronizada, posto que com um instrumento como a enxada o que poderia ser feito para aumentar e dar padrão de qualidade na produção?

Para justificar seu argumento recorria ao modo de análise que incutiu na Biologia Industrial. Assim, comparando com a fisiologia e medicina onde "não podemos estudar uma secreção normal ou mórbida” sem "reconhecer as diversas funções circulatórias ou nervosas que as regem”, entendia que o mesmo se daria com a Biologia Industrial. Com efeito, ao estudar a produção do café e encontrar seus problemas, suas lesões, tenta-se "considerá-lo em sua relação com o meio social”. Esse problema, ou mal, era "único” e "pode ser localizado na mão

\footnotetext{
401 COUTY, Louis. Étude de biologie industrielle sur le café, op. cit., 1883, p. 114.
} 
de obra". Esse mal "tem o nome de escravidão", logo o "escravo deve ser removido, ou antes, substituído". 402 Estava nisso "a verdadeira questão, a questão do Brasil neste fim de século, esta que resume a crise do café, e de outras dificuldades". Quanto a isso, segundo Couty, todo mundo sabia "e a necessidade de acabar o mais cedo com a escravidão" era "universalmente reconhecida”. ${ }^{403}$

Quando Couty diz acabar com a escravidão, ele não quer dizer abolição imediata, quer dizer imigração abundante somada à introdução de máquinas agrícolas, para que no correr breve do tempo não se perceba mais escravos trabalhando nas lavouras de café, pois só assim se daria a transição gradual por ele idealizada.

Em cada propriedade agrícola, a perda imposta ao senhor de escravos pelas depredações dos negros é considerável, principalmente nas fazendas de café. De nada vale trancar as senzalas durante a noite ou vigiar durantes o dia. Para roubar, o negro se torna industrioso e ativo, sabe dissimular e, no primeiro instante de liberdade, irá vender o produto de sua astúcia. ${ }^{404}$

Continuar com a mão de obra escrava diante de tudo que Couty apontou não seria a melhor solução para o futuro da lavoura cafeeira poderia pensar aqueles que compartilhavam das ideias de Couty. O trabalho e o comportamento do negro escravizado não teria correção ao olhar de Couty. Demandava um alto custo e os resultados produtivos não compensavam esse custo. Além

402 Idem, p. 114-115.

403 Idem, p. 115.

404 COUTY, Louis. A escravidão no Brasil, op. cit., 1988, p. 94. 
disso, se liberto fosse abandonaria o trabalho imediatamente, sobretudo porque, dizia ele anos mais tarde, "a própria libertação, apesar de seu propósito humanitário, em nada podia alterar os defeitos mentais e sociais dos atuais trabalhadores". ${ }^{405}$ Desse modo, Louis Couty estava reafirmando a necessidade da imigração ao descartar as possibilidades do negro evoluir e se adequar ao modo civilizado. Mostrava-se um ideólogo ativo da ideologia do branqueamento quando, com sua ciência, dizia ter os negros defeitos mentais inalteráveis.

\title{
4.5 A "falta de homens livres ativos"
}

\author{
Os homens livres da ordem escravocrata, ${ }^{406}$ que se \\ sentiam como "intrusos" no sistema como dizia Alfredo
}

\footnotetext{
405 COUTY, Louis. "Introdução”. In: O Brasil em 1884: esboços sociológicos, op. cit., 1984, p. 17.

406 Segundo a historiografia do assunto, constituídos à margem do sistema escravista deste o tempo da colônia, o contingente de homens livres recrudescia com processo abolicionista do século XIX. Assim, passavam distantes da disciplinarização do trabalho, ou seja, fora do binômio senhor e escravo. Com isso, se o referencial de trabalho era o do cativeiro, o entendimento que se tinha era de que a rejeição ao trabalho regular era porque todo e qualquer forma de trabalho manual era considerado como coisa de escravo e, portanto, degradante. KOWARICK, Lucio. Trabalho e Vadiagem: a origem do trabalho livre no Brasil. 2. ed. Rio de Janeiro - RJ: Paz e Terra, 1994, p. 43. Para uma discussão clássica do tema ver: FRANCO, Maria Sylvia de. Homens livres na ordem escravocrata. São Paulo: Editora UNESP, 1997. Gonçalves demonstra o papel da migração nordestina para a cafeicultura do centro-sul entre as décadas de 1870. GONÇALVES, Paulo Cesar. Migração e mão de obra: retirantes cearenses na economia cafeeira do centro-sul (1877-1901). São Paulo: Humanitas, 2006, p. 156.
} 
d'E. Taunay, ${ }^{407}$ era para Couty homens pouco ativos, descartados do seu pensamento, de seu projeto de colonização/civilização para Império. O trabalhador nacional é abordado em seu discurso como ilustração da necessidade da imigração e ao mesmo tempo torna-se ilustração da necessidade de uma abolição gradual. Nesses termos:

Foram realizadas tentativas de trabalho livre, em grande escala, mas, até agora, só se obteve sucesso em alguns serviços urbanos e em produções quase naturais como as da borracha, do tabaco, do mate e do cacau. Os progressos são efetivos, mas continuam sendo muito lentos em virtude da falta de homens livres ativos, aptos para os trabalhos agrícolas e capazes de uma atividade regular. ${ }^{408}$

Apesar de existir uma oferta de mão de obra livre, Louis Couty não entendia essa oferta de mão de obra constituída por homens ativos, ou seja, úteis no processo de abolição gradual proposto pela Lei do Ventre Livre (1871). Diante disso, se fosse abolida a escravidão em 1881, os fazendeiros não teriam mais como produzir diante da ausência de trabalho ativo disponível. Para Couty, os trabalhadores livres não realizavam uma atividade regular de trabalho; após certo período trabalhando não voltavam a trabalhar porque já se bastavam com o

407 Segundo Taunay, nas notas que fez em parceria com André Rebouças para o livro de Couty, o trabalhador nacional é vagabundo por não encontrar regalia alguma, "são homem oprimidos pela ideia de que são sempre intrusos e com justiça podem ser desalojados da terra que tem regado com seu suor. Daí a preguiça, o pouco amor ao local onde permanecem, mas que não the incute o sentido da estabilidade". COUTY, Louis. Pequena propriedade e Immigração Europeia, op. cit., 1887, p. 122. 408 COUTY, Louis. A escravidão no Brasil, op. cit., 1988, p. 51. 
que havia conseguido. Apesar de bons para obras difíceis e passageiras, "descansam quando têm algum dinheiro e não pensam em economizar" ${ }^{409}$ Outros empecilhos do uso do trabalhador livre se relacionavam à forma pela qual o trabalho escravo era visto pelos homens livres. Nesse sentido, "se o caboclo se recusa a dedicar-se a uma atividade agrícola regular, é porque não quer ser assimilado ao escravo". ${ }^{410}$ Inúteis no processo de organização do trabalho livre e no processo civilizador por qual passava o país, "Os caboclos, indolentes e apáticos, e os escravos precisam ser substituídos por trabalhadores diligentes, capazes de produzir, consumir e aproveitar as diversas facilidades das trocas. [...]". ${ }^{411}$

Ao mesmo tempo em que indicava um vácuo de produção ativa, indicava também quais elementos deveriam preencher esse espaço. Com isso, Couty mediava a organização do trabalho livre apontando um horizonte imigrantista. Seu trabalho ideológico nesse contexto foi suficientemente exitoso no ato de estabelecer os parâmetros do que precisava ser descartável e do que precisava vir e cobrir o que seria descartado no processo de organização do trabalho livre e, ao tempo, delineava, em bases científicas, um projeto civilizador imigrantista para o destino do país. O mais interessante em apontar no pensamento de Couty era no aspecto que ele não estava

409 COUTY, Louis. "Exploração e colonização”. (4 a 11 nov. 1883). In: O Brasil em 1884: esboços sociológicos, op. cit., 1984, p. 82.

410 COUTY, Louis. A escravidão no Brasil, op. cit., 1988, p. 88. Caboclo era um dos termos que Louis Couty utilizava para se referir aos homens livres nacionais.

411 COUTY, Louis. "As estradas de ferro". (6 jan. 1884). In: O Brasil em 1884: esboços sociológicos, op. cit., 1984, p. 170. 
pensando na mão de obra apenas, mas na constituição de um mercado interno de consumo, de um indivíduo que tinha necessidades, por isso os caboclos que se bastavam com o pouco que tinham não eram úteis nessa organização capitalista ${ }^{412}$ que se formava no Brasil. Além disso, os negros escravizados ao receberam a alforria não trabalhariam mais, ampliado o contingente de "vadios". Em seguida, dizia ele que:

O brasileiro verdadeiramente livre, aquele que pensa, que vota e que consome, representa uma pequena parte da massa da população; e em vez de ser lavrador, industrial ou artesão, ele visa a empregos políticos, administrativos ou outros que lhe pareçam mais importantes. É funcionário, médico ou engenheiro, é proprietário de escravos ou burocrata. ${ }^{413}$

Uma característica interessante que Couty atribui ao brasileiro verdadeiramente livre é a de que ele consome, que tem necessidades. ${ }^{414}$ Diferentemente ele vai

412 Segundo Kowarick, A apropriação de meios e instrumentos de produção, ao gerar lucros por meio da fabricação de bens para o mercado de consumo, constitui condição necessária para o surgimento do capitalismo. Contudo, para a realização disso, esses processos de produção precisam estar articulados de modo a criar excedentes mediante uma modalidade específica de subjugar o trabalhador. KOWARICK, Lucio. Trabalho e Vadiagem: a origem do trabalho livre no Brasil 2. ed. Rio de Janeiro - RJ: Paz e Terra. 1994, p. 11.

413 COUTY, Louis. "Exploração e colonização". (4 a 11 nov. 1883). In: O Brasil em 1884, op. cit., 1984, p. 80.

414 Segundo Berman, no século XIX, à medida que o mercado internacional se expandia, absorvia e destruía os mercados locais, com isso: "produção e consumo - e necessidades humanas - tornam-se cada vez mais internacionais e cosmopolitas”. BERMAN, Marshal. Tudo o que é sólido desmancha no ar, op. cit., 2013, p. 113. 
caracterizar a camada que ele não considera como cidadãos como sendo uma população que vive sem necessidades. Na medida em que se consome seria necessário uma produção ativa capaz de suprir as necessidades, do contrário ao se bastar com o pouco que tem não é interessante no desenvolvimento do país. Pensa ele num mercado interno ausente, que precisa ser desenvolvido e interligado ao mercado internacional, sendo isso um dos problemas do Brasil. A necessidade é o motor do progresso, da civilização, aquele que consome esta no topo, movimenta o mercado. Do outro lado estaria, para Couty, a população desajustada do sistema produtivo.

A presença dos escravos e junto deles vários milhões de camponeses, caboclos ou antigos agregados, sem atividade e necessidades, que ainda não são cidadãos úteis, pois não votam e não trabalham de maneira contínua, são a verdadeira causa da ausência de riqueza de valor das culturas e também da insuficiência dos impostos e das exportações. [...]. ${ }^{415}$

Analisando a sociedade de modo vertical, do escravo ao fazendeiro, notava Couty que a população brasileira possuía aproximadamente doze milhões de habitantes, sendo um milhão de índios e um milhão e meio de escravos. Restavam aproximadamente nove milhões de habitantes dos quais quinhentos mil era composto pelas famílias proprietárias de escravos: fazendeiros, advogados, médicos, funcionários, administradores, comerciantes.

415 COUTY, Louis. "Exploração e colonização”. (4 a 11 nov. 1883). In: O Brasil em 1884, op. cit., 1884, p. 80. [grifo nosso]. 
O grande problema para Couty estava nos seis milhões restantes, na população livre que, segundo ele, não era suficientemente preenchido. Eram seis milhões de habitantes que: "no mínimo, nascem, vegetam e morrem sem ter servido ao país". No campo, dizia ele "serão agregados de fazenda, caboclos, caipiras; nas cidades, capangas, capoeiras ou simplesmente preguiçosos e beberrões [...]". ${ }^{416}$

A verdadeira dificuldade de transformar o trabalho e aumentar a consequente produção não estaria na emancipação dos negros, mas sim na dificuldade em formar trabalhadores livres ativos. Na visão de Couty o contingente de homens livres "são menos que cidadãos, pois não são nem eleitores, nem consumidores, nem produtores". ${ }^{417}$ Era um povo improvável, não se daria como povo, seria um elemento não útil, que atrapalharia o amalgama social. Louis Couty pensava nas necessidades que fomentavam o mercado interno e externo e para isso era preciso um grupo social habilitado a produzir e, especialmente, a consumir. Sem consumo não há produção, sem produção não há progresso, sem progresso não há desenvolvimento científico, não há ciência.

Numa tentativa retórica de solucionar o problema dessa população marginalizada, Couty propõe dar aos 8 milhões de habitantes livres do Brasil a atividade dos habitantes dos Estados Unidos e Austrália "para que todas as dificuldades atuais fossem mais ou menos resolvidas". Contudo, observa o cientista que isso "não é possível porque não se muda a conformação dos cérebros e só

416 COUTY, Louis. A escravidão no Brasil, op. cit., 1988, p. 102.

417 COUTY, Louis. "Exploração e colonização”. (4 a 11 nov. 1883). In: O Brasil em 1884, op. cit., 1984, p. 81. 
lentamente se modificam os costumes de um povo". Assim, é necessário procurar "remédios mais rápidos", 418 ou seja, era preciso a transformação pela imigração europeia. A cada argumento Couty estabelecia uma ordem de como deveria se dar o progresso do Brasil, nesse processo o negro e o mestiço não teriam condições de serem assimilados numa conformação social útil ao destino do país porque para Couty a conformação do cérebro não se alterava. Daí a necessidade de branquear o país pela imigração europeia.

\subsection{0 imigrante europeu, o futuro}

O país que Louis Couty encontrou em 1879 era o país da escravidão. Até então, as primeiras experiências de uso do trabalho imigrante não haviam surtido bons resultados. ${ }^{419}$ Embora o malogro da experiência com o trabalho livre tivesse gerado restrições em países que enviavam contingentes de imigrantes para o Brasil, a vontade de atrair imigrantes para substituir o escravo continuava.

\footnotetext{
418 Idem, p. 80.

419 A primeira experiência do uso do trabalhador imigrante na produção cafeeira deu-se nas fazendas Ibicaba e Angélica, ambas as propriedades do Senador Vergueiro. Contudo, conflitos entre proprietário e colonos desencadeou o fim da experiência. Para uma compreensão do periodo e de outras experiências há uma ampla produção que tratou do assunto. Cf. HOLANDA, Sergio Buarque de. "Introdução". In: DAVATZ, Thomas. Memórias de um colono no Brasil. Belo Horizonte: Editora Itatiaia; São Paulo: Edusp, 1980. COSTA, Emilia Viotti. Da Senzala à Colônia. 2. ed. São Paulo: Ciências Humanas LTDA, 1982. STOLCKE, Verena; HALL, Michael M., "Introdução do trabalho livre nas fazendas de café de São Paulo”. In: Revista Brasileira de História, n. 6 , set. 1983.
} 
Com a década de 1870 inaugura-se uma nova fase na política imigratória brasileira: "a dos grandes contratos para a introdução de europeus”. Depois disso, o processo recrudesce até as grandes levas após meados da década de $1880 .{ }^{420}$

As reflexões de Louis Couty sobre o trabalho do imigrante tiveram como exemplo prático o que estava sendo feito na província de São Paulo. Embora Couty idealizasse também outros meios de atrair o imigrante, a experiência realizada pelos fazendeiros de São Paulo o agradava muito. Constantemente recorreu às ações que os fazendeiros paulistas estavam praticando para exemplificar que de fato, como ele pensava, "se o Brasil quer progredir só tem uma solução, a utilização da mão de obra livre fornecida pela Europa”. Não haveria outra solução e todos reconheciam que "somente a Europa pode fornecer ao Brasil esta mão de obra que falta”. ${ }^{421}$

Se as ideias de Couty sobre o "inferior" trabalho escravo eram analisadas e repercutidas na grande imprensa, suas ideias sobre o "superior" trabalho do imigrante também ganhavam os espaços dos jornais.

Provado como ficou no artigo precedente, graças aos dados fornecidos pelo trabalho do Dr. Couty, que a mão de obra escrava só deixa, ao produtor de café, lucro insuficiente - vamos tentar a demonstração inversa para a mão de obra livre,

420 GONÇALVES, Paulo Cesar. Mercadores de Braço: riqueza e acumulação na organização da emigração europeia para o novo mundo. São Paulo: Alameda, 2012, p. 149.

${ }^{421}$ COUTY, Louis. Étude de biologie industrielle sur le café, op. cit., 1883, p. 126-127. 
estudando a colonização tão ativa e, no entanto, tão ignorada, da província de S. Paulo. ${ }^{422}$

Com essas repercussões dos estudos de Louis Couty, o argumento favorável ao imigrante europeu tornava-se cientificamente comprovado. Nesse sentido, todo o percurso que Couty realizou para estudar o café e o trabalho empregado em sua produção, seus lugares de ação, seu capital científico, estavam pesando em seu argumento. Era a autoridade conceitual no assunto. ${ }^{423} \mathrm{O}$ artigo da Gazeta de Notícias se baseou no relatório sobre o café de 1883, sendo o artigo pouco posterior à publicação do relatório. Para tanto, os dados resultantes da comparação que Couty realizou entre o trabalho escravo e o trabalho livre serviram de fundamentação para o autor do artigo corroborar a superioridade do trabalho do imigrante europeu e, sobretudo, a necessidade de uma corrente imigratória para o Brasil.

Seguindo os dados fornecidos por Couty, o autor da Gazeta de Notícias asseverava que a província de São Paulo teria 30 mil colonos de fazenda. Eram colonos que

422 Gazeta de Notícias, 30 ago. 1883. Apesar de não constar autor, o título do artigo era "Vantagens do colono". Todavia, tudo indica que o autor do artigo "Vantagens do colono" é o mesmo que analisou o trabalho de Louis Couty no artigo "Inferioridade econômica do escravo". (21 ago. 1883).

423 Em uma nota a Gazeta da Tarde (29 de setembro de 1884) traz uma informação interessante de Couty na seção "Dia a Dia" da folha: "Consta que S. Ex. [Couty] vai ser, ou já está nomeado agente de colonização”. Em menos de dois meses dessa nota Couty morreria e talvez por isso não encontramos nenhuma outra informação sobre essa nomeação de Couty para a função de agente de colonização. Mas cabe ressaltar que essa nomeação de Couty demonstra que o que ele pensava estava sendo levado em consideração pelas autoridades do governo. 
ocupavam as terras cultivadas que, para Couty, seria de início a melhor colocação do colono recém-chegado da Europa. Com esses dados, segundo a Gazeta de Notícias, Couty "patenteia as vantagens que colhe o fazendeiro, substituindo o homem livre ao escravo". ${ }^{424}$

Enquanto que a produção escrava da região de Campinas e Limeira fornecia em média "60 mil arrobas por mil pés”, a produção colona seria “de cem arrobas por mil pés”. Com a mão de obra imigrante o cenário de aumento da produção estaria claro para o autor da Gazeta de Noticias:

Ao passo que um hectare de cafeeiro rende de $200 \$$ a $400 \$$ nas mãos dos escravos, rende de $500 \$$ a $600 \$$ com o colono; e a cultura do café mostra-se superior, não só aos cereais e à vinha, mas também à do açúcar, do algodão etc. ${ }^{425}$

Esses dados de Louis Couty, que o autor da Gazeta de Notícias utilizou para mostrar as vantagens do colono europeu, baseado nos exemplos práticos da província de São Paulo, demonstram que a repercussão e recepção dos argumentos de Couty sobre a superioridade do trabalho imigrante já faziam dele uma referência conceitual no assunto da mão de obra.

As ações e ideias de Louis Couty, seus textos e debates, constituíram, ao intervir, o contexto do amplo debate sobre a mão de obra na década de 1880, década que marcou o fim do regime monárquico e registrou uma

${ }^{424}$ Gazeta de Notícias, 30 ago. 1883.

425 Idem. 
forte corrente de imigrantes para o Brasil. Sua intervenção na questão da mão de obra se deu pelo modo que ele caracterizou a Biologia Industrial. Esta caracterização instrumentalizou sua ação e garantiu sensivel recepção nesse amplo debate. Se o Brasil não quer permanecer parado, "se quer fazer rapidamente sua emancipação, sem prejuizo para as culturas e exportações, se quer fazer cessar a crise do café, é urgente que prepare uma imigração mais ativa”. ${ }^{426}$ Nesses termos, Louis Couty tencionava unicamente a imigração, não pensava a emancipação dos negros senão em termos de perdas de produção, não cogitava o trabalho do negro como elemento ativo, apenas como elemento secundário no processo. Era o imigrante o único meio capaz de tirar o Império da crise. Posto que: "A imigração permite a cicatrização rápida da ferida da escravidão, como também permitirá aumentar, mais tarde, produções de café, de açúcar e de algodão que, já por falta de mão de obra, começam a diminuir". 427

\section{7 "O lado futuro do passado": Ces Yankees du Brésil428}

Felizmente, como a imigração já havia começado, pude convencer-me de que esta forma de colonização da terra cultivada era realmente adequada

${ }^{426}$ COUTY, Louis. Étude de biologie industrielle sur le café, op. cit., 1883, p. 160 .

427 COUTY, Louis. "A colonização e o estado”. (3 jan. 1884). In: O Brasil em 1884, op. cit., 1984, p. 148.

428 Segundo Louis Couty, "Yankees do Brasil" era a forma pela qual os paulistas se autodenominavam. Étude de biologie industrielle sur le café, op. cit., 1883, p. 129. 
ao percorrer as fazendas da inteligente província de São Paulo. ${ }^{429}$

Apesar de acreditar do potencial da imigração europeia, era preciso exemplos vivos e claros para que não houvesse argumentos contrários e para isso a imigração na província de São Paulo servia a Couty como um feliz convencimento. Os paulistas, segundo os cálculos de Couty, não se limitaram em triplicar em menos de vinte anos suas plantações de café, em cobrir a província de meios perfeitos de trabalho, de engenhos de café, de açúcar, manufaturas de algodão e de diversos produtos. Os paulistas não se limitaram "a construir em dez anos aproximadamente 1.500 quilômetros de ferrovia”. Sem a ajuda do governo imperial, enfatizava o francês, estes paulistas, "por própria iniciativa" encontraram uma maneira de substituir o negro pelo branco, l'homme libre à l'esclave. Num fôlego de modernidade e transformação, os paulistas, "pegaram o problema em sua base e levaram a província a se aproximar do fim do uso da mão de obra escrava" ${ }^{430}$

Nesse percurso - regiões cafeeiras do Vale do Paraíba e Oeste Paulista - em que desconstruía em bases escravistas para em seguida reconstruir em bases de trabalho livre a produção cafeeira e o Brasil, Couty fundamentava seu pensamento sobre a realidade do Império. Nessa fundamentação, esteve ele muito próximo dos principais

${ }^{429}$ COUTY, Louis. “Introdução”. In: O Brasil em 1884: esboços sociológicos, op. cit., 1984, p. 17.

${ }^{430}$ COUTY, Louis. Étude de biologie industrielle sur le café, op. cit., 1883, p. 129. 
fazendeiros paulistas, os fazendeiros do futuro como ele mesmo dizia.

Devo à gentileza de Soares Brandão, presidente da província; devo aos cuidados de homens como Tibiriçá, Antonio Prado, o Visconde de Indaiatuba, o Barão de Parnahyba, Vergueiro, Ferreira Camargo, de poder reunir sobre a colonização em São Paulo as observações numerosas e precisas que posso resumir: elas formam a parte verdadeiramente útil desta viagem, que deram a este relatório uma conclusão lógica, mostrando o lado futuro do passado. ${ }^{431}$

Os fazendeiros do passado e os fazendeiros do futuro representavam os dois lados de uma mesma moeda, uma moeda quase dividida diante das ações de um lado que permanecia prolongando o passado e do seu outro lado alcançando o futuro. Uma moeda cara e rara no lado passado, uma moeda rica em vias de tornar-se abundante na medida em que as ações seguiam os propósitos imigrantistas no lado futuro. No presente de Couty e de seus coevos podemos visualizar um esquema de temporalidades que relacionava o negro africano escravizado e o grande proprietário do vale do Paraíba com o passado, enquanto que o imigrante europeu que viria para trabalhar na pequena propriedade estaria relacionado com o futuro. Nesse sentido, a província de São Paulo representava o exemplo mais bem acabado do projeto idealizado por Louis Couty.

Para Couty, na crise atual, São Paulo "tem a certeza de poder atravessar" sem se arruinar, enquanto as

431 Idem, p. 129 
demais províncias se "organizam e se agitam". Estava aos olhos de todos que São Paulo era "o exemplo certo a seguir e o Brasil não tem necessidade de copiar países estrangeiros, como tenta frequentemente fazer: já encontra aqui mesmo seu próprio modelo" ${ }^{432}$ Numa crítica ao modo de conduzir a imigração por parte do Ministério da Agricultura, Couty notava que a província de São Paulo "soube corrigir os erros do governo geral". ${ }^{433}$

A província de São Paulo em suas ações tornava-se uma referência de como deveria ser conduzida a imigração no Brasil. Para Couty, a província de São Paulo "soube simultaneamente começar a construção de estradas de ferro e engenhos e povoar suas terras; ela possui uma produção e uma tecnologia importantes”. Nas demais províncias, Couty notava que "a iniciativa privada limitou-se quase que exclusivamente a instalar culturas e criações de animais, como no tempo dos portugueses, pautadas na escravidão e na grande propriedade". ${ }^{434}$ Enquanto São Paulo avançava rumo ao futuro, as demais províncias continuavam prolongando o passado. Os fazendeiros destas províncias, os fazendeiros do passado,

432 COUTY, Louis. "O Brasil no interior e os clubes da lavoura". (1 a 5 jun. 1884). In: O Brasil em 1884, op. cit., 1984, p. 249. Segundo Wilma Peres Costa, "as duas décadas finais da monarquia não foram um período de crescimento econômico, se considerarmos o país como um todo. A cafeicultura paulista e a exportação de borracha crescem em um cenário geral de estagnação". COSTA, Wilma Peres. "A questão fiscal na transformação republicana - continuidade e descontinuidade”. In: Economia e Sociedade, Campinas, n. 10, 1998, p. 143.

433 COUTY, Louis. "A colonização e o governo". (13 set. 1883). In: O Brasil em 1884, op. cit., 1984, p. 22.

${ }^{434}$ COUTY, Louis. "Hipoteca e exploração". (20 a 27 set. 1883). In: O Brasil em 1884, op. cit., 1984, p. 77. 
insistiam no "regime colonial português", que segundo Couty era "o pior dos regimes econômicos". Trabalhando as dimensões da crise e do atraso do Brasil, Couty atribuía ao colonizador português as mazelas consequentes de seu ato de trazer o negro africano e a escravidão para o Brasil. 435

Louis Couty comparou as províncias de São Paulo e Buenos Aires, sendo sua finalidade demonstrar que São Paulo era a melhor e a mais ativa em produção do que a província platina. Era mais um exemplo bem-sucedido da ação modernizante e civilizatória do imigrante europeu.

As promessas são às vezes difíceis de cumprir. Ao falarmos sobre o recenseamento da Província de Buenos Aires, tínhamos nos comprometido a demonstrar que aquela província tão florescente e progressista equivalia no Brasil, à de São Paulo. Estávamos enganados. São Paulo não é apenas equivalente a Buenos Aires; é superior em todos os aspectos. [Sic.] ${ }^{436}$

Tanto São Paulo quanto Buenos Aires e toda a produção que delas adivinham eram a demonstração que o Brasil deveria seguir o modelo imigrantista. Essa análise de Couty tornou-se muito importante para a imagem da província de São Paulo e do Brasil no exterior. Nesse sentido, Couty não poderia prever que seu livro, O Brasil em 1884, seria utilizado pela Sociedade Central de Imigração

435 COUTY, Louis. "Riqueza e trabalho". (18 nov. 1884). In: O Brasil em 1884, op. cit., 1984, p. 93.

436 COUTY, Louis. "São Paulo e Buenos Aires: comparação entre as duas províncias”. (14-17-21 fev. 1884). In: O Brasil em 1884: esboços sociológicos, op. cit., 1984, p. 151. 
a fim de contrapor os argumentos negativos sobre a produção cafeeira e o seu destino incerto descrito pelo holandês Delden Laerne em seu livro, porém o melífluo discurso de Couty se acomodou ao discurso da Sociedade Central de Imigração e engrossou o coro contra Van Delden.

Os dados falavam por si:

A produção do café em São Paulo multiplicou-se por seis em menos de 20 anos e quadruplicou desde 1872. Enquanto isso, a produção mais importante de Buenos Aires, a lã, nem mesmo dobrou, elevando-se de 69 milhões de quilogramas em 1870 a 92 milhões em 1880 e a 103 milhões $1881 .^{437}$

A província de São Paulo, as ações que nela estavam realizando seus principais cafeicultores e os resultados conquistados, ocupou lugar estratégico no projeto imigrantista que advém das ideias de Louis Couty quando apreendemos suas ideias num conjunto estruturado.

Em seu percurso pela região cafeeira do Rio de Janeiro e São Paulo evidenciou o que estava ocorrendo e as direções tomadas diante das ações empreendidas. Enquanto uma parte, especialmente, a região do Vale do Paraíba fluminense, se organizava em bases escravistas sem maiores medidas para uma alteração, a produção cafeeira do Oeste Paulista estava atribuindo "pesos equilibrados à relação entre o homem e o solo”, modificando a base do povoamento agrícola, "substituindo os precários e insuficientes organismos de produção por outros mais ativos e melhor organizados", sobretudo atraindo

437 Idem, p. 155. 
imigrantes. No pensamento de Couty, só haveria uma forma para realizar e espraiar tal obra, esta transformação necessária "só seria realizável com a imigração", ${ }^{438}$ só com a imigração o Império teria uma condição de civilização, só assim teria um povo verdadeiramente ativo.

\section{8 "'O Brasil não tem povo!'. É duro; mas é verdade"}

"Ainda a pouco um esperançoso escritor estrangeiro, aliás, nosso amigo, escreveu isto: 'a situação funcional da população brasileira pode ser expressa em uma só palavra: o Brasil não tem povo!' É duro; mas é verdade"439 dizia Sílvio Romero, um dos mais icônicos membros da geração intelectual de 1870, a respeito da formulação de Louis Couty. Partilhava Romero da opinião de Couty, enfatizando a necessidade de lutar para alterar esse problema, posto que a "questão não é só produzir café”, dizia ele, “Já é tempo de olharmos para traz, lançar as vistas sobre o caminho percorrido a quatrocentos anos e conhecermos que pouco, bem pouco, temos feito como nação culta” ${ }^{440}$

Louis Couty também lutava para a alteração desse problema, seu foco era alijar essa população, colocando-a em funções secundarias e entregar aos imigrantes a função de elevar o país à civilização. Buscando na história a explicação dessa ausência de povo, dizia Couty que com

438 COUTY, Louis. "Introdução”. In: O Brasil em 1884: esboços sociológicos, op. cit., 1984, p. 17.

439 ROMERO, Sílvio. "Introdução à história da literatura brasileira”. In: Revista Brazileira, tomo 9, p. 293, set. 1881.

440 Idem, p. 293. 
a independência o Brasil "infelizmente" daria continuidade aos desmandos da metrópole. E com isso, "este País imenso, desabitado, inexplorado, continuou fechado ou dificilmente acessível aos colonos livres da Europa, os únicos que seriam capazes de formar um povo e, com um povo, uma riqueza duradoura e produtiva" ${ }^{441}$ Couty também estava criticando a colonização portuguesa que havia legado ao Brasil "o pior dos regimes econômicos que jamais existiu num país novo: o regime colonial português". ${ }^{442}$

Nas discussões sobre o destino do país que marcaram as décadas de 1870 e 1880, a crítica à colonização portuguesa espraiou-se. Joaquim Nabuco nesse momento notava que "no princípio da nossa colonização, Portugal descarregava no nosso território os seus criminosos, as suas mulheres erradas [...]". ${ }^{443}$ Nesse momento, esses homens estavam elaborando o futuro do país e o exemplo de Portugal, a obra portuguesa, não deveria, em hipótese alguma, ser seguida na continuidade da história do Brasil. Era preciso rechaçar todas as possiveis continuidades, para que o Brasil, assim, alcançasse a civilização. Todos queriam a abolição da escravidão, mas cada um a sua maneira.

$\mathrm{Na}$ constituição dos elementos que formariam o povo brasileiro, Couty, ao analisar a situação do negro liberto, notava que o negro deixou de ser escravo, "mas não se tornou um cidadão verdadeiramente livre e útil”. ${ }^{444}$ Nessa análise racial do negro, Couty colocava toda

441 COUTY, Louis. A escravidão no Brasil, op. cit., 1988, p. 60. [grifo nosso] 442 COUTY, Louis. "Riqueza e trabalho". (18 nov. 1884). In: O Brasil em 1884, op. cit., 1984 , p. 93.

443 NABUCO, Joaquim. O abolicionismo, op. cit., 2000, p. 98.

444 COUTY, Louis. A escravidão no Brasil, op. cit., 1988, p. 64 
sua verve de cientista imbuída nas teorias racialistas que compunham as correntes de pensamento que revoava Império a fora. ${ }^{445}$

Couty argumentava em cima de uma condição prévia, a de que o escravo era inferior, sendo ausentes qualidades que só eram encontradas nos europeus. Hierarquizava-se a sociedade e justificavam-se lugares sociais preestabelecidos.

O difícil pagamento de impostos pouco elevados, as flutuações do valor do papel-moeda, a lentidão dos processos do aparelhamento nacional, as dificuldades para a imigração, a ausência de um povo efetivamente produtivo, em suma, todos os problemas econômicos especiais com os quais se preocupam, e com razão, os estadistas brasileiros, admitem, em grande parte, a mesma causa: a presença do escravo. ${ }^{446}$

\footnotetext{
445 Segundo Carula, "No século XIX, os discursos racialistas fizeram parte das abordagens de diversos pensadores das ciências naturais e sociais. Fosse pelo viés monogenista ou pelo poligenista, os trabalhos analisavam os meios natural e social, hierarquizavam a humanidade segundo critérios marcados pelo olhar europeu (ou simplesmente ocidental), branco e masculino. A existência de raças superiores e inferiores era comprovada por meio do discurso cientifico/cientificista, que vinha como portador da verdade inconteste”. CARULA, Karoline. Darwinismo, raça e gênero: conferências e cursos públicos no Rio de Janeiro (1870-1889). São Paulo: Tese (Doutorado em História Social) Departamento de História/FFLCH USP, 2012, p. 125-126.

446 COUTY, Louis. A escravidão no Brasil, op. cit., 1988, p. 87. [grifo nosso]. Segundo Gould, "Os deterministas muitas vezes invocam o tradicional prestígio da ciência como conhecimento objetivo, livre de qualquer tipo de corrupção social e política. Eles pintam a si mesmos como os detentores da verdade nua e crua e a seus oponentes como sentimentais, ideólogos e sonhadores. [...]”. GOULD. Stephen Jay. A falsa medida do homem. Tradução de Valter Lellis Siqueira. 3. ed. São Paulo: Martins Fontes, 2014, p. 4.
} 
Com isso dado, para justificar seu argumento de que não seria tão simples a assimilação de todas as raças humanas e fazê-las "desempenhar o mesmo papel social”, Couty evocava os fatos fornecidos por Huxley, Haeckel, Broca, Quatrefages e Hamy. ${ }^{447}$ Isto é, a causa era o escravo, mas sua liberdade não seria a solução para o país, pois o negro para Couty era incapaz de reconhecer os princípios da civilização. Para tanto, recorre à descrição de um encontro que ele e seu amigo Goffredo Taunay tiveram com um velho escravo que dizia ser um príncipe congolês.

Isto que nos foi dito por este filho de rei que passara mais de meio século no seio de uma sociedade civilizada, poderia nos ter sido dito por qualquer um de seus companheiros de cativeiro. Nenhum deles imagina, via de regra, que poderia ter tido uma vida diferente. Falar com eles em hebreu ou sânscrito seria tão difícil quanto fazer com que ele compreendesse, em pouco tempo, que poderiam ser elementos ativos de uma sociedade civilizada. ${ }^{448}$

Couty procurava demonstrar com o exemplo do africano escravizado que havia uma naturalização da ideia de ser escravo entre os negros. O escravo não concebia outra situação que não aquela. O príncipe, por exemplo, não entendia que poderia ter outra situação de vida e por isso não se queixava da "perda da liberdade ou a sua venda como escravo", sua queixa era contra seu primeiro senhor, considerado por ele como "violento e

${ }_{447}$ COUTY, Louis. A escravidão no Brasil, op. cit., 1988, p. 89. 448 Idem, p. 91 
brutal". Sendo o príncipe pouco interessado na liberdade - dos europeus. ${ }^{449}$

Esta liberdade, que outros indivíduos desejam tão avidamente a ponto de não hesitarem em transformar toda uma situação social para poderem consegui-la, os próprios negros a desejam sem paixão, e, para conquistá-la, quase todos se recusam a realizar qualquer esforço [...]. ${ }^{450}$

Desse modo, para Couty os negros escravizados desconheciam qualquer forma de instituições civilizadas. Por não ter os negros hábitos e costumes civilizados, não seriam eles aptos a constituir uma população ativa no Brasil. Além disso, dizia que o negro "não tinha noção de família nem de propriedade", ${ }^{451}$ elementos importantes na constituição da tão desejada civilização. Contudo, Couty observava que sob vigilância o negro trabalha arduamente, da mesma forma, a mãe negra, apesar de nem saber quantos filhos possui e de não visitá-los, alimenta-os com dedicação enquanto pequenos. ${ }^{452}$ Por outro lado, "nas famílias de colonos europeus, as mulheres desempenham um papel verdadeiramente civilizador juntando-se aos trabalhos na roça, especialmente na colheita”. 453

\footnotetext{
449 Idem, p. 91.

450 Idem, p. 91.

451 Idem, p. 95.

452 Idem, p. 95-96.

${ }^{453}$ COUTY, Louis. Étude de biologie industrielle sur le café, op. cit., 1883 , p. 121. O discurso científico procurava impor padrões de civilidade e à mulher caberia função estratégica na preservação, manutenção e busca da civilização. A respeito do papel civilizador da mulher pelo olhar dos médicos e cientistas Cf. CARULA, Karoline. Darwinismo, raça e gênero, op. cit., 2012.
} 
Ressaltava a importância do imigrante, sobretudo da mulher no seio familiar, demonstrando aspectos civilizados que justificavam a vinda do imigrante. O argumento do branqueamento da população seria, para Couty, um fator importante para o progresso do país, sobretudo porque, com o imigrante, a obra da civilização dar-se-ia tanto na casa com a mulher, quanto no trabalho com o homem.

A visão de Couty, e de muitos que com ele compartilhavam a ideia da inferioridade do negro, se estruturava no fato de que o negro era inferior, sendo isto um dado inquestionável para a ciência e para a sociedade de um modo geral. As doutrinas racialistas envolviam alguns pressupostos específicos, que visavam afirmar que os homens se diferenciavam em grandes grupos, as raças, os quais possuem certa unidade que lhes conferem determinadas características. Para alguns racialistas, a distância entre as raças era tão grande que as configuraria como espécies diferentes. ${ }^{454}$ Assim, Couty entrava nessas questões com o enunciado proposto de que o negro era inferior e todos os seus cálculos tinham que mostrar isso. Uma vez que, "a maior parte dos negros adultos apresenta muitas das características das crianças de nossas sociedades civilizadas". ${ }^{455}$ Demonstrar que o negro era uma criança grande se tornou recorrente no contexto do século XIX ${ }^{456}$ Contudo, "esta criança é demasiado velha

454 MAIO, Marcos Chor; SANTOS, Ricardo Ventura. Raça como questão: história, ciência e identidades no Brasil. Rio de Janeiro: FIOCRUZ, 2010, p. 29.

455 COUTY, Louis. A escravidão no Brasil, op. cit., 1988, p. 96.

${ }^{456}$ GOULD. Stephen Jay. A falsa medida do homem. Op. Cit. Segundo Gould, o anatomista francês Etienne Serres na década de 1860 "tratou de provar a existência de sinais de inferioridade entre as raças 
para que se possa transformá-la em pouco tempo”. Desse modo, Couty queria anular qualquer possibilidade de utilização do negro tanto como mão de obra, quanto como povo útil. Seria um risco, para Couty, utilizar o negro como elemento constituinte do que viria a ser o povo brasileiro, posto que "o fato de seus caracteres étnicos e sociológicos serem comparáveis aos de nossa primeira evolução não impede que estes sejam traços definidos e imutáveis, que exigem várias gerações para poderem se modificar". ${ }^{457}$ Isto é, não havia tempo suficiente para esperar o aperfeiçoamento do negro ou do mestiço. No seu diagnóstico, o Brasil só sairia da crise se utilizasse outro elemento em sua estruturação social, o branco europeu.

O pressuposto das diferenças raciais se organizou no século XIX em oposição à visão Iluminista de uma humanidade unitária. Como assegura Schwarcz, a ideia de raça no final do século XIX se aproximava à noção de povo. Desse modo, o discurso racial aparecia como variante do debate sobre a cidadania, já que no interior desses novos modelos discorria-se mais sobre determinações do grupo biológico do que sobre o arbítrio do indivíduo, entendido como um resultado de sua raça. ${ }^{458}$

primitivas. Como anatomista, procurou essas provas no domínio de sua especialidade e confessou que não era fácil especificar critérios e dados. Ele se contentou com a teoria da recapitulação, segundo a qual as criaturas superiores passam, durante seu processo de crescimento, por vários estágios que correspondem aos dos animais inferiores. Os negros adultos, afirmava ele, corresponderiam às crianças brancas, e os mongólicos adultos aos adolescentes brancos. [...]”, op. cit., p. 27. 457 COUTY, Louis. A escravidão no Brasil, op. cit., 1988, p. 97.

458 SCHWARCZ, Lilia Moritz. O espetáculo das raças, op. cit., 2008, p. 47. 
O indivíduo seria determinado pelo grupo racial a qual pertence. $^{459}$

$\mathrm{Na}$ divisão dos capítulos de seu livro O Brasil em 1884, o último capítulo justifica-se pelo nome: O futuro. O primeiro artigo do capítulo também: Revolução, evolução, ação. Nesse artigo Couty faz uma análise do indivíduo a partir do que ele chamou de "duas grandes doutrinas", que se dividiam e dividia o mundo do pensamento. Para "os espiritualistas", o pensamento deriva de uma força imaterial, "cuja gênese e regras escapam aos nossos meios de investigação”. Esta força é chamada "de alma", oriunda de outra mais ampla: "a divindade". Esta divindade, dizia Couty, é dotada "de atributos ainda mais obscuros, o bem, o belo, a pré-ciência”. A este lado, estavam os homens que no Brasil "proclamam em alto e bom som o direito dos escravos à libertação, esquecendo que os negros são escravos na África, em seus países de origem, ligam-se à escola espiritualista e metafísica que busca numa autoridade suprema invisivel, insondável e indemonstrável o alvo das ações do homem”. Couty tenciona demonstrar, à sua visão, que se os abolicionistas "fossem lógicos e consequentes, sua divisa deveria ser: sucumba o Brasil e não um princípio". ${ }^{660}$

Do outro lado, de sua análise, estavam os materialistas que afirmam que "todos os fenômenos físicos, biológicos ou sociológicos são da mesma natureza”. Dessa corrente originava o materialismo científico que

459 MAIO, Marcos Chor; SANTOS, Ricardo Ventura. Raça como questão, op. cit., 2010, p. 29.

460 COUTY, Louis. "Revolução, evolução, ação”. (17 abr. 1884). In: O Brasil em 1884, op. cit. 1984, p. 237-238. 
"tomou outras formas mais insidiosas". Enquanto "Claude Bernard tentava, sob o nome de 'determinismo', reduzir todos os fenômenos vivos, psíquicos ou fisiológicos a formas especiais mais complexas dos atos físico-químicos”, por suas vezes,

Darwin, Huxley, Haeckel, Broca e principalmente Spencer formulavam uma nova doutrina para a matéria viva, a da 'evolução'; e depois de Lamarck, Comte, Malthus e outros precursores inconscientes, tentavam aplicar aos fenômenos sociais esta lei biológica, com seus fatores cegos de adaptação e seleção. ${ }^{461}$

Com essa argumentação, Louis Couty visava demonstrar que para essas doutrinas a individualidade desaparecia e que "por conseguinte, o homem tem apenas que se deixar arrastar no meio do conjunto das forças materiais que ele constata e admira sem poder modificar”. Em decorrência disso: "O poder do homem é nulo". Disso resultava que "as descobertas científicas que pensa ter realizado, os progressos higiênicos e morais por que luta são resultantes em que o esforço pessoal poderia ser negligenciado". Desse modo, Couty afirmava que "materialismo, espiritualismo, evolução, revolução são nomes que devem desaparecer se se quiser legar ao homem seu verdadeiro papel de individualidade pensante e agente [...]". Posto que, "a liberdade humana não é um direito ou um principio; é um fato, variável e contingente, como a combinação dos sais ou a germinação de um grão”.

Contudo, esse fato, segundo Couty, "apresenta uma modalidade especial" que separa "completamente

461 Idem, p. 238. 
os fenômenos materiais, psicológicos e sociais, dos fenômenos materiais biológicos ou físico-químicos”. Isto é: a "individualidade pensante ativa e livre é capaz de intervir nas mudanças que a cercam”. Com efeito, todos

os fatos demonstram que o homem reagiu no espaço e no tempo contra os fenômenos exteriores físico-químicos ou biológicos. Em vez de adaptar, ele aos poucos criou habitações, vestimentas, métodos de aclimatação, de domesticação, meios de defesa e de transporte, equipamentos diversos que se sofisticam cada dia mais. ${ }^{462}$

É interessante notar que, com essas análises sobre o indivíduo, Couty estava corroborando o discurso racialista/determinista de que em grupo ou isoladamente o negro seria inferior. Justificava que o negro era inferior, não só racialmente, mas como indivíduo. Por não ser o negro um indivíduo útil e ativo ele precisava ser rechaçado do processo civilizador por qual deveria passar o país. Louis Couty indicou essa análise em 1881 com a publicação do livro A escravidão no Brasil quando asseverava que: "O fato importante e capital vai nos ser fornecido pelo estudo dos costumes e das características sociais, e não pelo estudo das raças e dos caracteres étnicos”. Isto porque, segundo ele: "No Brasil, o liberto entra plenamente em uma sociedade na qual ele é imediatamente tratado como igual, ao passo que nas Antilhas e, especialmente na América do Norte, ele continua a ser, geralmente, um pária”. Desse modo, o escravo disporia "de meios para

${ }^{462}$ Idem, p. 238-240. 
sair, por si só, de sua condição", ${ }^{463}$ mas não saía porque segundo Couty "o negro no Brasil só pede uma facilidade, um direito: o de não fazer nada" ${ }^{464}$ Os fins eram os mesmos, mudavam-se os meios da justificativa. Isto é, para Couty, em uma sociedade que oferecia plenas condições de evolução, só não evoluíam aqueles que eram biologicamente e sociologicamente incapazes de por si chegar ao nível de civilizado.

A questão do povo na história do Brasil sempre esteve associada aos temas da mestiçagem e da escravidão. Esta preocupação percorre a história do país desde a colônia, mas foi a partir do século XIX que o tema ganhou mais relevância. A questão do povo é tão instigante que foi classificada por Francisco Weffort como "tema primordial da história das ideias no Brasil". 465

A análise de Louis Couty sobre o povo foi partilhada em sua época por Sílvio Romero, mais tarde Romero retomaria a questão da ausência de povo quando da recepção a Euclides da Cunha na Academia Brasileira de Letras em 1906. ${ }^{466}$

Ao mesmo tempo em que tinha suas ideias partilhadas pelos homens de seu tempo, Couty era veementemente criticado pelo movimento abolicionista. Quanto a

\footnotetext{
463 COUTY, Louis. A escravidão no Brasil, op. cit., 1988, p. 53.

464 Idem, p. 93. [grifo de Couty]

465 WEFFORT, Francisco C. Formação do Pensamento Politico Brasileiro: ideias e personagens. São Paulo: Ática. 2006, p. 328-329. Para um exame historiográfico da questão Cf. FALCON, Francisco. "O povo brasileiro: ensaio historiográfico”. In: Revista USP, São Paulo, n. 46, 2000, p. 30-41.

466 CARVAlHO, José Murilo. "Os três povos da República”. In: Revista USP, São Paulo, n. 59, 2003, p. 96-115.
} 
isso, a Gazeta da Tarde publicava em 1881 um artigo em que contestava os argumentos de Couty sobre sua ideia de considerar a escravidão como útil para o Brasil, mas que a liberdade do negro seria prejudicial à nação. Com efeito, lançava uma questão: "Por que motivo o Sr. Couty não formula de um modo mais categórico a demonstração da incapacidade do negro? Por que apenas atira certos postulados contra os quais protestam os fatos?". ${ }^{467}$ Todavia, Louis Couty seguia em sua convicção sobre a ausência de povo no Brasil. Em 1884 era sua vez de citar Sílvio Romero e acrescia o abolicionista Joaquim Nabuco no debate. A mestiçagem era a questão:

Seus defensores, aqueles que, com Sílvio Romero, julgam o mestiço superior ao branco, ou seus contendores, aqueles que, com Joaquim Nabuco, lamentam o fato de o país ter sido colonizado pelos portugueses e pelos negros, chegam à mesma conclusão: o Brasil não tem povo, ou melhor, o povo que the foi dado pelas misturas de raças e pelas alforrias não desempenha um papel ativo e útil. ${ }^{468}$

Na década de 1880 as discussões sobre o problema da mão de obra, sobre os destinos do país, mobilizavam um intenso debate que o próprio Couty colocava a necessidade de ser no futuro estudado. Nesse debate, como discussão, o povo era ativo. Com suas formulações sobre o povo, ou sua ausência, Couty sedimentava aspectos do cientificismo na imagem do Brasil como possuidor de

467 Gazeta da Tarde, 18 jul. 1881.

468 COUTY, Louis. "Imigrantes e libertos". (7 - 11 maio 1884). In: O Brasil em 1884, op. cit., 1984, p. 200. 
uma população atrasada - que precisava ser melhorada pela ação da imigração do branco -, de um povo improvável de ser representante do ideal de civilização que as elites buscavam. Sílvio Romero confirmava o diagnóstico de Couty ao aceitar que "que pouco, bem pouco, temos feito como nação culta”. ${ }^{469}$

Somando todos os caracteres raciais do negro, do índio e do mestiço, tal equação não teria como resultante um povo como o povo europeu, daí a alternativa imigrantista era a solução na mente de Couty e dos seus. Solução que não deveria se alongar no tempo, sendo urgente a necessidade de medidas que resolvessem a equação inconclusa do povo brasileiro. Buscava-se um substituto ao trabalho escravo, não apenas ao trabalho, mas ao indivíduo negro também. Queria-se um indivíduo regrado no trabalho e, bem por isso, a obra do português colonizador, implementador da escravidão, precisava ser rechaçada, a aventura do português devia ser substituída pelo trabalho organizado, profícuo, suficientemente capaz de pôr em prática a estruturação de um mercado interno e inserir o país numa ordem moderna de civilização. As teses de Couty iam ao encontro dos interesses das elites quanto ao tocante do branqueamento e modernização do país pela imigração europeia. Foi Couty um profícuo ideólogo do branqueamento, sedimentou imagens que, ao mesmo tempo, divulgava o Brasil como um paraíso, sem conflitos raciais e por outro lado demonizava a população existente ao insistir no discurso de que daquela camada da sociedade não poderia sair um povo.

469 ROMERO, Sílvio. "Introdução à história da literatura brasileira”, op. cit., 1881, p. 293. 


\subsection{Apreender ideias, revelar projetos}

Enfático em suas ações e pensamento, Louis Couty procurava incentivar reformas que facilitariam a vinda $\mathrm{e}$ a vida do imigrante. Foi contrário a qualquer ação que não tivesse a imigração europeia somada à introdução de máquinas na produção agrícola como alternativa. A solução para o futuro do país só seria possível pela imigração, do contrário disso dizia ele: "só existem o empirismo e a revolução armada, isto é, a derrocada total da importante produção do Brasil e das suas províncias mais florescentes". ${ }^{470}$

Contrário desde o princípio a uma abolição total, Couty estabelecia um projeto de ações que deveriam acontecer para que se estabelecesse uma corrente contínua de imigrantes europeus. Esse projeto imigrantista de Louis Couty encontra-se de modo mais prático e amplo no livro O Brasil em 1884. Prático porque estruturava os meios pelos quais deveria ser realizada a imigração, além de citar exemplos estabelecidos. Amplo porque se inseria numa corrente de ideias imigrantistas que ganhava mais força a partir da década de 1880 .

O livro O Brasil em 1884 é resultado de uma reunião de artigos que Louis Couty publicou na imprensa francesa da Corte entre os anos de 1883 a 1884, num total de quarenta e quatro. Todos os artigos reunidos foram publicados na folha Le Messager du Brésil. O livro foi publicado originalmente em francês pelos editores Faro \& Lino.

${ }^{470}$ COUTY, Louis. "Introdução”. In: O Brasil em 1884, op. cit., 1984 , p. 18. Esta reflexão continha críticas ao movimento abolicionista com o qual travou longo debate sobre os destinos do negro e do Império. 
Louis Couty tornou-se diretor do Le Messager du Brésill $^{471}$ além de criar outro periódico de publicação bimestral, Revue de France et du Brésil. Tinha projetos para a colônia francesa da Corte, como relatou o professor Gorceix num necrológio, Couty pensava em organizar uma escola francesa, "com professores que houvessem todos pertencidos à Universidade e que serviria de modelo para o ensino secundário no país". ${ }^{472}$ Pensou o país além do ponto de vista de um viajante. Estava estabelecido e pensava a partir desse ponto. Muito disso estava em seus debates, quando seus opositores questionavam suas ideias estrangeiras, ele replicava baseado em seus interesses de estabelecer vida no país.

Existe melhor prova de nossa confiança no futuro do Brasil do que o fato de que, na medida de nossas forças, procuramos ajudar a prepará-lo? Se acreditássemos, como alguns, no naufrágio do navio, será que perderíamos nosso tempo discutindo sobre os meios de reconduzi-lo ao rumo mais seguro, mais amplo e mais fácil? Temos a mais absoluta confiança no futuro do Brasil e só temos dúvidas quanto aos meios pelos quais esse futuro será alcançado. Será que esses meios serão pacificos? Desejamos intensamente que assim seja $e$ achamos isso possivel, se soubermos tomar imediatamente as medidas de povoamento e de transformação necessárias. ${ }^{473}$

471 Le Messager du Brésil tinha sede de sua redação e administração na Corte, Rua Sete de Setembro, número 131. Era publicado duas vezes na semana. Após a morte de Couty a folha deixou de existir.

472 "Biografia: L. Couty julgado pelo professor Gorceix". Gazeta Médica da Bahia, série 3, v. 2, p. 413, 1884-1885.

${ }^{473}$ COUTY, Louis. "As culturas do Brasil e seu rendimento" (10 a 13 abr. 1884). In: O Brasil em 1884, 1984, p. 101. [grifo nosso]. 
O seu interesse no Brasil encontra-se também em várias de suas decisões. Quando convidado a voltar para a França, não aceitou o convite e permaneceu com suas funções no Império. Essa era sua missão de homem de ciência, agente da civilização. De fato, Louis Couty também pensou a imigração de um ponto de vista pessoal. Não deixava de ser ele um imigrante em terras desconhecidas. Contudo, era um imigrante que ocupava funções destacadas e fundamentais no governo imperial. Foi bem recebido pela sociedade e assim queria que essa boa recepção se espraiasse para com os demais compatriotas franceses ou compatriotas de continente.

No livro O Brasil em 1884, vamos notar as ações e ideias de Louis Couty com uma dinâmica interessante. Todos os temas que Couty abordou nesses artigos estão inseridos no contexto do problema da mão de obra: escravidão, trabalho do nacional livre, imigração, colonização, ferrovias, café, hipotecas, pequena e grande propriedade, e a constituição do povo sombreando as discussões. Além disso, tocou em questões que se interligavam a demanda pelas reformas que, ao chegar os imigrantes, era preciso que fossem realizadas: secularização dos cemitérios, grande naturalização, casamento civil para o imigrante, medidas contra o estrangeirismo - que era, em seu entendimento, o preconceito contra imigrantes. Todas essas questões analisadas por Couty saíram em forma de artigo na imprensa francesa da Corte. Eram publicados a cada semana ou com maior espaçamento no período de dois anos, entre 1883 a 1884 . Esse é o primeiro aspecto da intervenção das ideias de Couty. Outro aspecto se relaciona a recepção e apropriação e mobilização de suas ideias no contexto em que elas foram elaboradas. 
Entre os anos de 1883 e 1884, Louis Couty atuou na redação do Le Messager du Brésil. Ali estavam materializadas as possibilidades de agir em prol de uma imigração útil para o Império. Seus textos, nesse período, ambientam a construção mais clara de suas ideias imigrantistas e de um projeto de colonização para o Império do Brasil.

Até 1883, Louis Couty escreveu/publicou relatórios, proferiu palestras públicas, ministrou cursos, publicou livros, realizou várias missões científicas e de comércio no Império e fora dele. Foi a partir de 1883, ano que publicou seu relatório sobre o café, que Couty começou a escrever seus artigos e divulgar amiúde suas ideias de um lugar de conforto, da colônia francesa da Corte, da sede do Messager du Brésil. Somados a este lugar francês, havia os outros estabelecimentos de Couty já tratados aqui, a Escola Politécnica, o Museu Nacional, que garantiam a ele a autoridade científica no assunto. Além disso, apresentou a definição mais bem acabada do modo pelo qual desenvolveu a chave interpretativa de análise da sociedade brasileira, o método pelo qual operou os problemas que no caminho encontrou, isto é, a Biologia Industrial. Louis Couty trouxe a público, de forma mais precisa, a definição de Biologia Industrial em 1883 com o relatório Étude de biologie industrielle sur le café. Desde então seus artigos no Le Messager du Brésil vão conter a marca de sua interpretação singular sobre o Brasil. Desse modo, da análise desses artigos somados aos outros livros revela-se o que denominamos de projeto imigrantista de Louis Couty.

Os problemas sociais hoje existentes no Brasil estão de tal forma interligados que devem ser resolvidos reciprocamente se não quisermos anular o 
passado, perder o que já possuímos e recomeçar $a b$ ovo a utilização das províncias mais importantes do país. Entretanto, é fácil classificar as reformas mais urgentes sob três títulos diferentes: imigração, isto é, substituição dos escravos por trabalhadores mais ativos e mais econômicos; medidas para a utilização dos antigos habitantes, caboclos ou libertos; medidas gerais para a tecnologia e para o câmbio. ${ }^{474}$

Louis Couty priorizou em seu projeto as reformas a partir de três pontos: imigração; medidas para a utilização do homem livre nacional e o incremento tecnológico no aparato agrícola somado às questões cambiais. Contudo, é a imigração e a substituição dos escravos a prioridade como demonstramos até aqui. De uma forma interessante, Couty estruturava suas ideias no texto diagnosticando o problema e mostrando a solução, em síntese, o problema era o trabalho escravo e a solução a imigração europeia. Contudo, apesar de não ver uso no trabalho do liberto que se somaria ao trabalho do nacional livre, colocava como possibilidade a utilização do trabalhador nacional. O uso do trabalhador nacional livre seria à guisa das orientações de Spencer, isto é, ocupando funções secundarias no processo de produção nacional.

[...] o negro e o mestiço têm muita aptidão para desempenhar certas funções sociais, como, por exemplo, aquelas que Spencer tão bem resumiu sob a designação de funções de distribuição ou de relação, mas continuam ineptos para as mais

474 COUTY, Louis. "As medidas necessárias”. (15 abr. 1884). In: O Brasil em 1884, op. cit., 1984, p. 231. 
importantes, as funções de produção, que requerem um trabalho continuado e regular. ${ }^{475}$

Um dos aspectos que utilizou para justificar funções secundárias do negro na divisão do trabalho se orientou na concepção determinista, sendo esse modo tão importante para Couty em suas definições que, segundo ele, "não existem nações onde a divisão do trabalho não tenha sido o produto de diferenças biológicas". 476 $\mathrm{Na}$ análise de Couty, portanto, tanto o negro liberto quanto nacional livre, sendo que ao ser liberto o negro tornar-se-ia membro da grande massa de homens livres, seriam inseridos na estrutura produtiva da sociedade em funções secundárias. O protagonismo produtivo caberia ao trabalho imigrante, que viria trazer todas as inovações tecnológicas necessárias para suplantar a enxada do negro e seu inferior trabalho. Para que o Império tornasse atrativo ao imigrante era preciso uma série de reformas que facilitariam a vinda e a permanência desse colono.

Nesse projeto de imigração que Couty desenvolveu, era preciso oferecer aos imigrantes as terras cultivadas, pois nelas o imigrante iria produzir mais que o negro escravizado. Após certo tempo a trabalhar e a melhorar de vida no Brasil o imigrante "escreverá então a todos os parentes e amigos dizendo que no Brasil se pode economizar depressa porque as culturas são fáceis e lucrativas". Com isso, o fluxo de "imigração espontânea se criará por si próprio, sem despesas nem lutas; e esse fluxo produzirá logo uma mão de obra capaz de assegurar [a]

475 COUTY, Louis. A escravidão no Brasil, op. cit., 1988, p. 103.

476 Idem, p. 104. 
manutenção das explorações atuais e aumentá-las mais tarde". ${ }^{47}$ Do contrário, se os imigrantes chegarem ao Brasil e forem enviados às terras virgens "voltará desencorajado; ou, se lá ficar, gastará muito e será pouco útil”. Era preciso, portanto, que a imigração tivesse uma direção, a das terras cultivadas. Resulta dessas constatações seu projeto imigrantista para o país.

Uma forma de colonização da terra cultivada proposto por Couty consistia no "cultivo das terras marginais às estradas de ferro, na compra dessas terras, na sua divisão em pequenos lotes destinando-se cada um a uma família de imigrantes. [...]”. Nesse argumento revela um traço interessante de seu projeto imigrantista, dizia ele que aplaudia a fundação da Sociedade Central de Imigração, mas que desejava "resguardar a nossa liberdade de ação e, certos de que os iniciadores dessa obra não suspeitam de nós, aproveitamos a oportunidade para discutir com eles um meio de colonização pelo qual parecem ter muito apreço" ${ }^{478}$ O meio era a colonização marginal às estradas de ferro. É interessante notar que Couty sentia necessidade de autonomia reflexiva em relação às questões imigrantistas e de colonização. Antes de ter suas ideias atreladas à organização da Sociedade Central, Couty reivindicava uma autonomia, resguardando suas ideias ao seu projeto, que poderia ulteriormente ser apropriado pelas organizações imigrantistas.

477 COUTY, Louis. "As culturas do Brasil e seu rendimento". (10 a 13 abr. 1884). In: O Brasil em 1884, op. cit., 1984, p. 107.

478 COUTY, Louis. "A colonização da terra cultivada: suas condições atuais”. (30 dez. 1883). In: O Brasil em 1884, op. cit., 1984, p. 109. [grifo nosso]. 
Em relação à forma de colonização das terras cultivadas, informava os exemplos bem-sucedidos dos Estados Unidos e procurava referendar seus argumentos citando uma revista francesa de inspiração econômica: "Ainda hoje, na Flórida, no Dakota e no Colorado instalam-se colonos nessas condições, e podemos encontrar informações sobre o assunto em diversos números recentes do Economiste français". Além dos Estados Unidos, outros lugares esse sistema de colonização havia sido empregado, caso da Argentina. Com efeito, reconhecia que esse sistema poderia "prestar serviços ao Brasil". ${ }^{479}$

No Congresso Agrícola do Rio de Janeiro em 1878, o marechal Henrique de Beaurepaire Rohan discutiu essa forma de colonização às margens das linhas férreas citando o que dizia o fazendeiro José Vergueiro.

O Sr. Vergueiro aconselha que ao longo das vias férreas e em terrenos férteis se estabeleçam, quanto antes, núcleos para a colonização ou emigração, e está convencido de que os particulares irão aos poucos, e segundo seus recursos, adotando a medida, que deve ser o zelo posto em prática pelo Governo Imperial. Esses núcleos terão por base: arrendamento e venda. Aconselha mais que no centro desses estabelecimentos se formem pequenas povoações, onde, à guisa do que se observa no Norte da Europa, encontre o colono o vizinho, o amigo, os recursos da vida [...]. ${ }^{480}$

\footnotetext{
479 Idem, p. 109.

480 ROHAN, Henrique de Beaurepaire. "O futuro da grande lavoura e da grande propriedade no Brasil. Memória apresentada ao Ministério da Agricultura, Comércio e Obras Públicas. In: Anais do Congresso Agrícola do Rio de Janeiro, 1878. Introdução e notas de José Murilo de Carvalho. Fundação Casa de Rui Barbosa. Edição fac-similar, 1988, p. 245.
} 
Interessante contrastar o que disse Rohan e Vergueiro com Couty, posto que Couty veio reforçar tal iniciativa e sua necessidade para atração de imigrantes. Nesse cenário da expansão férrea, Couty notava que em 1883 o Império havia realizado, em quinze anos, "consideráveis progressos em sua tecnologia nacional; construiu quase mil quilômetros de estradas de ferro", que durante o mesmo período outras obras foram realizadas, porém a imigração era "insuficiente em relação às necessidades". Para Couty toda a tecnologia empregada deveria servir ao imigrante, descartando assim os outros trabalhadores. Para tanto, citava um discurso de Alfredo d'E. Taunay: "Esse país constrói estradas de ferro, mas não quer imigração", e reforçava a necessidade da imigração. ${ }^{481}$

No projeto de Couty, o imigrante deveria ocupar as melhores terras, as já cultivadas, estar próximo das vias de transportes e receber pequenos lotes para produzir. Ao liberto, ao caboclo, isso não caberia, posto que, segundo a lógica de Couty, esses trabalhadores eram ineptos e possuíam a marca da irregularidade no trabalho, não produziam como produzia um colono europeu.

Nesse seu projeto de imigração, de civilização para o Brasil, a uma classe cabia lugar de destaque, a classe dos fazendeiros a "mais ativa e mais inteligente que as outras". Posto que, foram os fazendeiros que "fizeram a força e a riqueza nacionais”. Interessante que Couty anula a participação do trabalho do africano escravizado ao dizer que os fazendeiros "abriram e desbravaram as matas

481 COUTY, Louis. “Tecnologia e povoamento”. (9 ago. 1883). In: O Brasil em 1884, op. cit., 1984, p. 26. 
virgens, instalaram as grandes culturas de açúcar e de café; foram eles que construíram as estradas, as usinas e as estradas de ferro importantes". Ao anular a ação de trabalho dos trabalhadores escravizados nesse processo de construção do Brasil, Couty exalta a individualidade empreendedora daquele que, para ele, pode salvar o Brasil da crise que poderia levar o país à ruína se não organizar o processo de substituição do trabalho escravo pelo trabalho livre. ${ }^{482}$

Essa classe de fazendeiros não é fechada como as antigas aristocracias francesa ou russa. Muito diferentes dos lordes ingleses, com os quais são comparados sem nenhuma razão, os fazendeiros não estão protegidos por nenhuma lei especial de impostos ou de herança. Se eles representam uma aristocracia, esta aristocracia está fundamentada em seus próprios esforços. [...]. ${ }^{483}$

Couty insere os fazendeiros numa ordem moderna de sociedade, são eles empreendedores, na medida em que eles incentivam tudo aquilo que Couty listou. Foi pelo esforço e não pela herança consanguínea que eles fizeram a riqueza queria dizer Couty. Por isso, por esse esforço seriam eles os mais capazes de conduzir o processo de substituição do trabalho escravo pelo trabalho livre. Quando Couty tecia elogios aos fazendeiros, estava ele elogiando um grupo de fazendeiros que Couty chamou de fazendeiros do futuro, que em sua maioria se localizavam

482 COUTY, Louis. "A Lei de São Paulo e a Colonização da Terra Cultivada”. (20-27-30 mar. 1884). In: O Brasil em 1884, op. cit., 1984, p. 216. 483 Idem, p. 216. [grifo nosso]. 
na província de São Paulo. Por isso, se colocava contra aqueles que transformavam "esta classe num verdadeiro bode expiatório, que explicaria todas as dificuldades apenas por sua simples presença”. ${ }^{484}$ Nesse caso, Couty analisa a crise do Brasil por uma origem a mão de obra escrava do negro africano que veio pela ação do colonizador português. Para Couty, esta era a origem do problema do Brasil e não os grandes proprietários.

Em "um certo número de fazendeiros", os do passado, Couty observa os obstáculos para a divisão da grande propriedade em lotes para pequenos proprietários. É a possibilidade da divisão, da transformação de imigrantes em pequenos proprietários, que vai atrair uma corrente de imigrantes para o país. Por isso, era necessário convencer os fazendeiros do passado:

De que não se trata de acabar com as fazendas nem de transformar todos os colonos em pequenos proprietários. Deseja-se simplesmente converter aos poucos as fazendas em grandes vilarejos; e como nos Estados Unidos e na República Argentina, deseja-se criar progressivamente uma mistura de grandes proprietários, de meeiros, de arrendatários, de assalariados, numa palavra, de homens livres de todas as classes. ${ }^{485}$

Outras medidas deveriam ser tomadas para que o colono imigrante se sentisse confortável para vir ao Brasil e permanecer no país. Essas medidas que Louis Couty abordou em seus artigos e livros se relacionam às

${ }^{484}$ Idem, p. 217.

485 Idem, p. 222. [grifo nosso]. 
reformas de modernização que tomaram conta do Império em sua década final. A questão era simples para o cientista, para realizar a colonização era "preciso fazer reformas sociais absolutamente indispensáveis na esfera do povoamento e da propriedade". ${ }^{866}$ Sem tais reformas a colonização não se daria em pleno êxito.

$\mathrm{Na}$ perspectiva de Louis Couty algumas questões precisavam ser resolvidas para que a corrente imigratória se fizesse e se cumprisse em pleno êxito. O "estrangeirismo" era um comportamento que precisava ser rechaçado. Segundo Couty, o estrangeirismo era uma forma de se relacionar própria de Portugal, mas que havia eivado o jeito de ser do brasileiro. Estrangeirismo era a desconfiança do estrangeiro, mas do estrangeiro que não é português. Esse estrangeirismo constitui o que Couty chamou de "caráter social perfeitamente definido". Esse caráter próprio do brasileiro, mas herdado de Portugal explicava:

A ausência de naturalização, a religião do Estado com o estado civil nas mãos dos padres, uma lei de contratos como a de 1879 , o pouco sucesso das tentativas de colonização e, sobretudo, é ela [a desconfiança própria do estrangeirismo] que explica os fatos tão nocivos que se reproduzem todos os dias. [sic]. ${ }^{487}$

Os fatos nocivos do cotidiano eram, por exemplo, "a interdição de produtos farmacêuticos franceses" que, por sua vez, eram "vendidos no mundo inteiro". Essa

486 COUTY, Louis. "As culturas do Brasil e seu rendimento". (10 a 13 abr. 1884). In: O Brasil em 1884, op. cit., 1984, p. 108.

487 COUTY, Louis. "O estrangeirismo”. (20 dez. 1883). In: O Brasil em 1884, op. cit., 1984, p. 99. 
aversão em firmar contrato sem necessariamente conhecer o outro, prevalecendo a desconfiança ao invés da fiança gerava infortúnios ao povo brasileiro como a "Questão Tripoti”, ou seja, o impedimento por parte do governo italiano da saída de colonos, "cada dia mais necessários", para o Brasil. ${ }^{488} \mathrm{O}$ estrangeirismo era um problema que fomentava outros problemas que, por sua vez, deveriam ser levados em consideração na medida em que atrapalhava a vinda do imigrante tão desejado.

Diante disso, uma série de reformas seria necessária. A regulamentação do casamento civil era uma das medidas a serem executadas em prol de reformas. ${ }^{489}$ Além dessa questão do casamento civil, outras ações deveriam acontecer.

A grande naturalização, a igualdade de religiões e o registro civil são as primeiras condições do progresso social. Estamos convictos de que essas reformas, já aceitas pela maioria dos brasileiros cultos, já propostas às Câmaras por homens como Taunay, Silveira Martins, Saldanha Marinho, L. de Carvalho e Maciel, farão logo parte das leis do País; e a última lei eleitoral, votada graças aos esforços do Sr. Saraiva, já realizou grande progresso nesse sentido. Mas um outro obstáculo poderoso ainda permanecerá no âmbito dos costumes e é preciso lutar contra ele para fazê-lo desaparecer. ${ }^{490}$

488 Idem, p. 100.

489 COUTY, Louis. "O casamento civil”. (11 abr. 1884). In: O Brasil em 1884, op. cit., 1984, p. 229. Para Louis Couty a regulamentação do casamento civil seria um grande avanço para o Brasil e daria autonomia de ação aos individuos, op. cit., p. 229.

490 COUTY, Louis. "Nacionais e estrangeiros". (4 maio. 1884). In: O Brasil em 1884, op. cit., 1984, p. 193. 
É interessante contextualizar o trecho acima, pois ele vem em decorrência de um longo debate sobre os destinos dos negros e do Império que Couty travou com o movimento abolicionista, especialmente o ligado à Gazeta da Tarde. Couty é afirmativo em considerar os ataques da Gazeta da Tarde como sendo atos de estrangeirismo, por isso ele lutava contra esse "vicio social" e em favor dos imigrantes que "trouxeram para o Brasil mais ou menos todas as suas indústrias, suas artes, suas culturas. Os franceses ensinaram, em quase toda parte, a arte do fabrico do pão, do sapato, das vestimentas, a arte dos restaurantes, das modas [...]". ${ }^{491}$ Listou uma série de feitos que atribuiu aos imigrantes franceses. Nessas afirmativas de Louis Couty notamos os meios pelos quais ele delineou um projeto de imigração e de defesa dos interesses dos imigrantes a fim de que estes fossem assimilados como cidadãos de fato num país onde seriam estrangeiros. Por isso, essas medidas de facilitar a naturalização, o casamento civil, a secularização dos cemitérios - o problema da religião de Estado -, facilitar a compra de pequenas propriedades e a sua luta contra o vício do estrangeirismo, estavam inseridas no âmbito de um projeto pessoal. Sua ação a partir de 1883 se deu nesse aspecto, de facilitar ao máximo a vinda e a permanência dos imigrantes.

Nesse projeto imigrantista de Couty é interessante notar a evolução da ideia da atuação do Estado na condução da imigração.

Enfim, o Estado intervém diretamente para orientar os novos habitantes e mais tarde obrigá-los a

491 Idem, p. 192. 
se tornarem cidadãos. Nesse sentido oferece-lhes, em condições de fácil pagamento, grandes faixas de terra própria para a cultura ou para a criação de animais, com possibilidade de lucro imediato. ${ }^{492}$

No trecho acima Couty mostra como foi a ação do Estado nos Estados Unidos, com a criação de estabelecimentos para a recepção dos imigrantes. Nesse caso, ele objetiva uma ação direta do Estado. Poucos meses depois ele vai renunciar essa ideia de maior intervenção do Estado. Dizia que "ninguém defende mais a colonização pelo Estado", sobretudo porque "nenhum país tentou sob essa forma de condições”, ao se referir às colônias do Estado. O governo não deve promover o povoamento, "deve apenas facilitá-lo”. Posto que, "sua intervenção direta custa muito caro”. E dizia: "Já renunciamos a ela; é de se esperar que não voltemos atrás". ${ }^{493}$

De fato, Couty não voltou atrás nessa concepção de ação do Estado na condução da imigração para o Império. Ele vai definir melhor essa ideia ao notar que "o Estado deve intervir. Não poderá ficar sempre na expectativa [...]”. Contudo, coloca-se de modo contrário a uma ação direta e exclusiva do Estado nos modos de arregimentar a mão de obra para o Império. Ao Estado caberia, "através de uma série de medidas”, ser um agente que visasse "facilitar a ação dos particulares, em especial dos grandes proprietários, que precisam de mão de obra e não podem

492 COUTY, Louis. “A colonização e o governo”. (13 set. 1883). In: O Brasil em 1884, op. cit., 1984, p. 24.

493 COUTY, Louis. “Exploração e colonização”. (4 a 11 nov. 1883). In: O Brasil em 1884, op. cit., 1984, p. 86. 
diretamente obtê-la". ${ }^{494}$ Deve-se a sociedade agir em conjunto, o Governo e as organizações civis para realizar as reformas necessárias e garantir o futuro do Império.

Em vez de substituir diretamente lotes de terras virgens e pequenas casas, como fez até agora, o que custa caro e não resolve a crise de trabalho escravo nem satisfaz os imigrantes, o Estado deve simplesmente facilitar a instalação de empresas ou sociedades que começarão a divisão das fazendas endividadas entre os colonos já bem de vida e que mais tarde farão o povoamento das terras devolutas, como fizeram nos Estados Unidos e na Austrália. ${ }^{495}$

O Estado na concepção de Couty deveria agir de forma a facilitar a ação dos indivíduos organizados em empresas ou sociedades, a fim de que estas agissem. Seus elogios à fundação da Sociedade Central de Imigração se relacionam a esta forma de entender a função do Estado. Anunciando o aparecimento de várias associações no ano 1883, entre elas a da Liga do Ensino, Sociedade dos Letrados e etc., notava Couty que, com isso, "estas repetidas eclosões, sem união aparente, demonstram a importância que tomou nesse país uma força até então rudimentar, a iniciativa associada". Isso era a demonstração de que "os indivíduos já deixaram de esperar o que quer que seja desta divindade vaga, mutável e muitas

${ }^{494}$ COUTY, Louis. "A colonização da terra cultivada: suas condições atuais”. (30 dez. 1883). In: O Brasil em 1884, op. cit., 1984, p. 112.

495 COUTY, Louis. "As medidas necessárias". (15 mar. 1884). In: O Brasil em 1884, op. cit., 1984, p. 232-233. 
vezes parcial chamada Estado". ${ }^{496}$ Era o Brasil mais ativo que tanto queria Couty. Esse movimento interno de associativismo seria útil na vulgarização dos produtos do Império com a ação do Centro da Lavoura e na atração de imigrantes com a Sociedade Central.

Louis Couty, homem de ciência, mas também de comércio, publicista, amigo do Brasil, protagonista no debate sobre os destinos da mão de obra e do Brasil, trilhou um percurso que no tempo foi curto, mas amplo no significado e nas ações. Seu projeto imigrantista para o Brasil poder ser compreendido, na medida em que deslindamos seu percurso, analisamos seus textos, apreendemos o modo pelo qual ele interpretou o Brasil e forjou esse amplo projeto imigrantista.

$\mathrm{Na}$ "estupenda relação de trabalhos científicos e sociológicos", como se referiu Alfredo d'E. Taunay ${ }^{497}$ aos trabalhos de Couty, notamos, após analisá-los num conjunto estruturado, que o projeto imigrantista de Louis Couty partia de um ponto de vista pessoal, pois tinha como lugar de ação o impresso Le Messager du Brésil. Contudo, não foi a partir de sua ação no Le Messager du Brésil que passou a acreditar na imigração como meio de alçar o Império no caminho do progresso e da civilização, mas foi no Le Messager du Brésil que empregou todo seu conhecimento, após suas missões e diagnósticos, sobre o Império e direcionou suas críticas e sugestões de como deveria ser realizada a imigração. Sua atuação como

496 COUTY, Louis. "O Brasil no exterior e o Centro da Lavoura e Comércio”. (25 maio 1884). In: O Brasil em 1884, op. cit., 1984, p. 250. 497 TAUNAY, Alfredo d'E. Estrangeiros ilustres e prestimosos no Brasil (1800-1892), op. cit., 1932, p. 43-60. 
publicista, e ele se colocava como um publicista, tornou-se o meio pelo qual suas ideias agiram no contexto dos debates sobre a mão de obra na década final do Império do Brasil. Com efeito, o projeto de Louis Couty se organizava em decorrência de suas observações na produção cafeeira das províncias do Rio de Janeiro e São Paulo. Em decorrência dessas observações pelas regiões cafeeiras, vai criticar o trabalho do escravo ao considerá-lo pouco produtivo, vai descartar o trabalhador nacional livre ao considerá-lo como incapaz de manter regularidade no trabalho; e, ao atribuir as melhores características ao trabalho livre do imigrante europeu, vai propor como solução da crise que acometia a produção do café a vinda de imigrantes. Para que esses imigrantes viessem era preciso reformas e ações. É interessante notar que a condução desse processo caberia ao fazendeiro, o do futuro como dizia ele, que em conjunto com as medidas estabelecidas pela Lei do Ventre Livre, engataria o país no progresso rumo à civilização. Entendemos deste modo descrito o projeto de Louis Couty.

Revelamos os lugares, o percurso e a formação das ideias de Louis Couty sobre a sociedade brasileira de final dos Oitocentos, agora é importante demonstrar como tais ideias foram assimiladas pela Sociedade Central de Imigração, órgão que teve destacada atuação na organização da imigração para o Brasil no final do século XIX. 